\title{
The nutritional and health attributes of kiwifruit: a review
}

\author{
David P. Richardson ${ }^{1}$. Juliet Ansell ${ }^{2}$. Lynley N. Drummond ${ }^{3}[$
}

Received: 10 August 2017 / Accepted: 27 January 2018 / Published online: 22 February 2018

(c) The Author(s) 2018. This article is an open access publication

\begin{abstract}
Purpose To describe the nutritional and health attributes of kiwifruit and the benefits relating to improved nutritional status, digestive, immune and metabolic health. The review includes a brief history of green and gold varieties of kiwifruit from an ornamental curiosity from China in the 19th century to a crop of international economic importance in the 21st century; comparative data on their nutritional composition, particularly the high and distinctive amount of vitamin C; and an update on the latest available scientific evidence from well-designed and executed human studies on the multiple beneficial physiological effects.

Of particular interest are the digestive benefits for healthy individuals as well as for those with constipation and other gastrointestinal disorders, including symptoms of irritable bowel syndrome. The mechanisms of action behind the gastrointestinal effects, such as changes in faecal (stool) consistency, decrease in transit time and reduction of abdominal discomfort, relate to the water retention capacity of kiwifruit fibre, favourable changes in the human colonic microbial community and primary metabolites, as well as the naturally present proteolytic enzyme actinidin, which aids protein digestion both in the stomach and the small intestine. The effects of kiwifruit on metabolic markers of cardiovascular disease and diabetes are also investigated, including studies on glucose and insulin balance, bodyweight maintenance and energy homeostasis.

Conclusions The increased research data and growing consumer awareness of the health benefits of kiwifruit provide logical motivation for their regular consumption as part of a balanced diet. Kiwifruit should be considered as part of a natural and effective dietary strategy to tackle some of the major health and wellness concerns around the world.
\end{abstract}

Keywords Kiwifruit $\cdot$ Nutritional composition $\cdot$ Vitamin $C \cdot$ Digestive health $\cdot$ Metabolic benefits

\section{Introduction}

Kiwifruit are a nutrient-dense fruit and extensive research over the last decade on the health benefits of kiwifruit has linked their regular consumption to improvements not only in nutritional status, but also benefits to digestive, immune and metabolic health. The health benefits of consuming fruit are well documented [1]. Kiwifruit are exceptionally high in vitamin $\mathrm{C}$ and contain an array of other nutrients, notably nutritionally relevant levels of dietary fibre, potassium,

Lynley N. Drummond

drummondl@mac.com

1 DPR Nutrition Ltd., 34 Grimwade Avenue, Croydon, Surrey CR0 5DG, UK

2 Zespri International Ltd., 400 Maunganui Road, Mount Maunganui 3116, Tauranga, New Zealand

3 Drummond Food Science Advisory Ltd., 1137 Drain Road, Killinchy 7682, New Zealand vitamin $\mathrm{E}$ and folate, as well as various bioactive components, including a wide range of antioxidants, phytonutrients and enzymes, that act to provide functional and metabolic benefits. The contribution of kiwifruit to digestive health is attracting particular attention owing to a growing body of evidence from human intervention studies. There are several plausible mechanisms of action that are likely to act together including the fibre content and type, the presence of actinidin (a natural proteolytic enzyme unique to kiwifruit which breaks down protein and facilitates gastric and ileal digestion $[2,3])$, and other phytochemicals which may stimulate motility [4].

The kiwifruit of commercial cultivation are large-fruited selections of predominantly Actinidia deliciosa cv Hayward (green kiwifruit) and an increasing range of gold varieties of various Actinidia species. The Hayward cultivar is an ovalshaped berry with a dull brown hairy skin, however, one of its most attractive features is the strikingly beautiful appearance of the bright translucent green flesh interspersed with 
several rows of small black seeds. As an example of a gold fleshed kiwifruit Zespri® Sungold (Actinidia chinensis spp.) have a bright yellow flesh surrounded by a smooth, hairless, bronze-coloured skin. The flesh of the green Hayward cultivar is described as a tangy, sweet and sour combination providing a unique flavour combination, whereas the gold cultivar is described as having a sweet and tropical taste $[5,6]$.

\section{History}

In the twentieth century, kiwifruit came a long way from being a wild species partially exploited by man to being a commercial crop of international economic importance [7]. Kiwifruit are native to the temperate forests of the mountains and hills of southwest China. Missionaries in the nineteenth century made many contributions to the advancement of botany and the distribution of horticultural plants [8]. The first botanical specimens of A. chinensis were sent to Europe by the Jesuit priest Père Pierre Noël Le Chéron d'Incarville around the 1750s and later by Robert Fortune, a plant collector. Robert Fortune was sent to China by the Horticultural Society of London (1843-1845) to "collect seeds and plants of an ornamental or useful kind", and one of Fortune's specimens of A. chinensis was held at the Royal Botanic Gardens at Kew, London. The first fruits of A. chinensis to be seen in Europe were sent, preserved in spirit, to Kew in 1886. Today New Zealand is a major producer of kiwifruit, and all early commercial varieties of kiwifruit plants in New Zealand and around the world can be traced back to a Church of Scotland mission station in Yichang, China, in 1878. Early in the twentieth century, the seeds and plants were regarded as ornamental curiosities with no mention of the edible fruit. The introduction of kiwifruit to New Zealand can be traced to a school teacher, Isabel Fraser, who in 1904 returned from a visit to China with seeds [7]. Around 1922, Hayward Wright, a nurseryman living near Auckland, New Zealand, offered plants in his catalogue, listing the plant as "a wonderful fruiting climber" and promoting it as a highly valuable new fruit because it ripens in the winter over a long period, thus making the fruit a valuable addition to the short supply of winter fruits.

The Hayward cultivar has been sold widely from the late 1930s and the dominance of this cultivar worldwide is now complete. The first commercial orchards and large-scale plantings occurred around this time. Orcharding kiwifruit required brave and courageous decisions as the work was hard, there were no proven patterns of management by growers and agronomic problems were faced as they occurred. World War II and then agricultural and marketing incentives from the 1950s to the present day resulted in the rapid geographical expansion of orchards in New Zealand, Australia,
Chile, USA and Europe, mainly Italy, France and Greece. In Italy, the high content of vitamin $\mathrm{C}$ gave kiwifruit the reputation of being the "frutto della salute"- the health fruit [8].

The last 100 years have seen the domestication of the kiwifruit from being a wild plant (the so-called "Chinese gooseberry") to a stage where it is now an important crop in several countries. The name "kiwifruit" was proposed by Turners and Growers Ltd, an exporting firm in Auckland, after the flightless bird, which is endemic to, and often taken as, the emblem of New Zealand. Servicemen were also commonly known as "Kiwis", and by 1969 the name kiwifruit was well established and accepted.

The process of domestication of kiwifruit is a fascinating and complex story. It includes botanical identification, the collection of seeds and propagating material, cultivation techniques to grow and manage the plant, the management of a dioecious perennial climber, selection of the best cultivars, the commercial discoveries of the cultural conditions affecting yield, harvesting, storage, packing to extend the season and transporting across the globe [8].

Of all the different species of Actinidia, the main cultivar of economic importance is A. deliciosa, and all the commercial plantings in New Zealand can be traced back to the seeds introduced by Isabel Fraser. The geographic range, the diversity of the wild population and subsequent development of cultivars, including gold and red-fleshed varieties, indicate that the gene pool, mostly sourced from wild types in China, offers many opportunities for breeding programmes for many desirable attributes, including very high levels of vitamin C [5, 9]. Whilst the kiwifruit season requires winter growing, the fruit can be stored very well once harvested and also is produced in both the northern and southern hemispheres. This means that kiwifruit is available throughout the year which is important for those interested in regular consumption for its health benefits [10].

\section{The nutritional attributes of kiwifruit}

Comprehensive and independent data on the nutritional composition of kiwifruit can be found in the USDA National Nutrient Database for Standard Reference [11] and the New Zealand Food Composition Database (NZFCD) [12]. Chemical analyses are conducted on fruit ripened to the "ready-to-eat" state to ensure that the data are reflective of what would normally be consumed. Typically, kiwifruit (A. deliciosa and A. chinensis_-"green" and "gold" cultivars, respectively) are eaten with the skin removed, and hence the analyses shown in Table 1 are completed on the edible flesh portion only. A recent update to this information in the NZFCD now includes nutritional composition of the skin, as there is anecdotal evidence of 
Table 1 Nutritional composition of kiwifruit (Source: USDA

National Nutrient Database for

Standard Reference Release 28, green and gold raw kiwifruit per 100g [11])

\begin{tabular}{|c|c|c|c|}
\hline Nutrient & Units/100 g & Green Kiwifruit & Gold Kiwifruit \\
\hline \multicolumn{4}{|l|}{ Proximates } \\
\hline Water & $\mathrm{g}$ & 83.1 & 82.4 \\
\hline Energy & kcal & 61 & 63 \\
\hline Energy & $\mathrm{kJ}$ & 255 & 262 \\
\hline Protein & $\mathrm{g}$ & 1.14 & 1.02 \\
\hline Total lipid (fat) & $\mathrm{g}$ & 0.52 & 0.28 \\
\hline Ash & $\mathrm{g}$ & 0.61 & 0.47 \\
\hline Carbohydrate, by difference & $\mathrm{g}$ & 14.7 & 15.8 \\
\hline Fiber, total dietary & $\mathrm{g}$ & 3 & 1.4 \\
\hline Sugars, total & $\mathrm{g}$ & 9.0 & 12.3 \\
\hline \multicolumn{4}{|l|}{ Minerals } \\
\hline Calcium, $\mathrm{Ca}$ & $\mathrm{mg}$ & 34 & 17.0 \\
\hline Iron, $\mathrm{Fe}$ & $\mathrm{mg}$ & 0.31 & 0.21 \\
\hline Magnesium, $\mathrm{Mg}$ & $\mathrm{mg}$ & 17 & 12.0 \\
\hline Phosphorus, $\mathrm{P}$ & $\mathrm{mg}$ & 34 & 25 \\
\hline Potassium, K & $\mathrm{mg}$ & 312 & 315 \\
\hline Sodium, Na & $\mathrm{mg}$ & 3 & 3 \\
\hline Zinc, Zn & $\mathrm{mg}$ & 0.14 & 0.08 \\
\hline Copper, $\mathrm{Cu}$ & $\mathrm{mg}$ & 0.13 & 0.103 \\
\hline Manganese, Mn & $\mathrm{mg}$ & 0.098 & 0.05 \\
\hline Selenium, Se & $\mu \mathrm{g}$ & 0.2 & 0.44 \\
\hline \multicolumn{4}{|l|}{ Vitamins } \\
\hline Vitamin C, total ascorbic acid & $\mathrm{mg}$ & 92.7 & 161.3 \\
\hline Vitamin B1-Thiamin & $\mathrm{mg}$ & 0.027 & $<0.01$ \\
\hline Vitamin B2-Riboflavin & $\mathrm{mg}$ & 0.025 & 0.074 \\
\hline Vitamin B3-Niacin & $\mathrm{mg}$ & 0.341 & 0.231 \\
\hline Vitamin B5-Pantothenic acid & $\mathrm{mg}$ & 0.183 & 0.12 \\
\hline Vitamin B6-Pyridoxine & $\mathrm{mg}$ & 0.063 & 0.079 \\
\hline Vitamin B9-Folate & $\mu \mathrm{g}, \mathrm{DFE}$ & 25 & 31.0 \\
\hline Choline & $\mathrm{mg}$ & 7.8 & 1.9 \\
\hline Vitamin B-12 & $\mu \mathrm{g}$ & 0 & 0.08 \\
\hline Vitamin A, RAE & $\mu \mathrm{g} \_\mathrm{RAE}$ & 4 & 1 \\
\hline Vitamin A & $\mathrm{IU}$ & 87 & 23 \\
\hline Vitamin E ( $\alpha$-tocopherol) & $\mathrm{mg}$ & 1.46 & 1.51 \\
\hline Vitamin $\mathrm{K}$ & $\mu \mathrm{g}$ & 40.3 & 6.1 \\
\hline \multicolumn{4}{|l|}{ Others } \\
\hline Carotene, beta & $\mu \mathrm{g}$ & 52 & 14 \\
\hline Lutein + zeaxanthin & $\mu \mathrm{g}$ & 122 & 24 \\
\hline Scientific Name: & & Actinidia deliciosa & Actinidia chinensis \\
\hline Cultivar & & Hayward & SunGold \\
\hline USDA NDB No & & 09148 & 09520 \\
\hline
\end{tabular}

growing number of consumers who choose to eat the skin, particularly of the gold varieties since it is smoother, thinner, and hairless. Consumption of whole SunGold kiwifruit (including the skin) increases the fibre, vitamin $\mathrm{E}$ and folate contents by 50, 32 and $34 \%$, respectively [13].

\section{Vitamin C}

The total ascorbic acid content is the most distinctive nutritional attribute of kiwifruit [12]. The levels in the Hayward green cultivar are typically between 80 and $120 \mathrm{mg}$ per $100 \mathrm{~g}$ fresh weight [14]. This natural variation of amounts of vitamin $\mathrm{C}$ in fruit, including kiwifruit, is due to numerous 
factors including growing region and conditions, use of fertilisers, maturity at harvest, time of harvest, storage and ripening conditions [15]. In terms of nutritional value, using scoring models that rank and compare the amount of important nutrients present in foods, kiwifruit score well against other fruit. This provides a useful means for communicating those nutritional benefits to consumers [16-18], and should be noted that the high nutrient density score is largely driven by their high vitamin $C$ content [12]. Figure 1 compares the vitamin $\mathrm{C}$ content of various fruits to that of Hayward and SunGold kiwifruit cultivars. The SunGold kiwifruit contains $161.3 \mathrm{mg}$ vitamin C per $100 \mathrm{~g}$-almost three times the amount found in oranges and strawberries on an edible flesh weight basis.

From the technical and sensory perspectives, the high ascorbic acid and low tannin content in kiwifruit are thought to explain why the cut fruit does not develop the typical browning reaction that occurs in most other fruits [14].

Vitamin C (ascorbic acid) is an essential dietary nutrient for humans, as we lack the terminal enzyme L-gulono$\gamma$-lactone oxidase in the ascorbate biosynthetic pathway [19]. There is an absolute requirement for Vitamin $\mathrm{C}$ for a range of biological functions. Vitamin $\mathrm{C}$ is a cofactor of metallo-enzymes necessary for the biosynthesis of collagen, L-carnitine, catecholamine, neurotransmitters, and peptide hormones such as oxytocin [20,21]. Vitamin C in involved $\mathrm{a}$ in the regulation of transcription factors [22]. The strong antioxidant properties of Vitamin $\mathrm{C}$ are well documented, it scavenges free radicals and other reactive oxygen and nitrogen species, with a capacity to regenerate other small molecule antioxidants from their respective radicals [23, 24]. Thus, it protects biomolecules such as lipids and DNA against oxidative damage $[25,26]$.

There is evidence from in vitro, as well as animal and human intervention studies that supports the role of vitamin $\mathrm{C}$ in the functioning of the immune system. Leukocytes, which are cells responsible for defending the body against invading pathogens, contain high levels of vitamin C, indicating a vital function in the immune system [27]. These cells include neutrophils, the first cellular responders to inflammatory challenge. Their primary function is to destroy invading microorganisms and thereby prevent systemic infection [28, 29].

A recent Cochrane systematic review [30] upholds the role of vitamin $\mathrm{C}$ in improving immune function and reducing the duration of common cold symptoms in the ordinary population. A Gold kiwifruit intervention study showed enhanced plasma vitamin $\mathrm{C}$ concentration and reduced severity and duration of upper respiratory infection symptoms in 32 elderly people supplemented with four kiwifruit per day for 4 weeks [31].

An effectively functioning immune system is crucial for maintaining physiological integrity, and the European Food Safety Authority (EFSA) Panel on Dietetic Products, Nutrition and Allergies (NDA) [32] considers that maintaining normal immune function is a beneficial physiological effect. Given the multiple roles of the immune system providing defences against infections and allergic manifestations such as asthma, urticaria and eczema, the specific effect on immune function is required for scientific substantiation of health claims on a food/constituent. The requirements for substantiation of health claims on maintaining normal immune function in a population group considered to be at risk of immunosuppression (e.g., older adults, individuals experiencing stress or engaging in heavy physical exercise, or after exposure to ultraviolet radiation) are provided in the scientific opinion of EFSA [32].

The vitamin C content of green and gold kiwifruit is 92.7 and $161.3 \mathrm{mg}$ per $100 \mathrm{~g}$, respectively [11]. In the European Union, the Reference Intake (RI) for vitamin C for labelling purposes is $80 \mathrm{mg}$ [33]. For "source" and "high" nutrient content claims for vitamin $\mathrm{C}$, the amounts required for the
Fig. 1 Graph comparing the vitamin $\mathrm{C}$ content of kiwifruit with other commonly consumed fruit

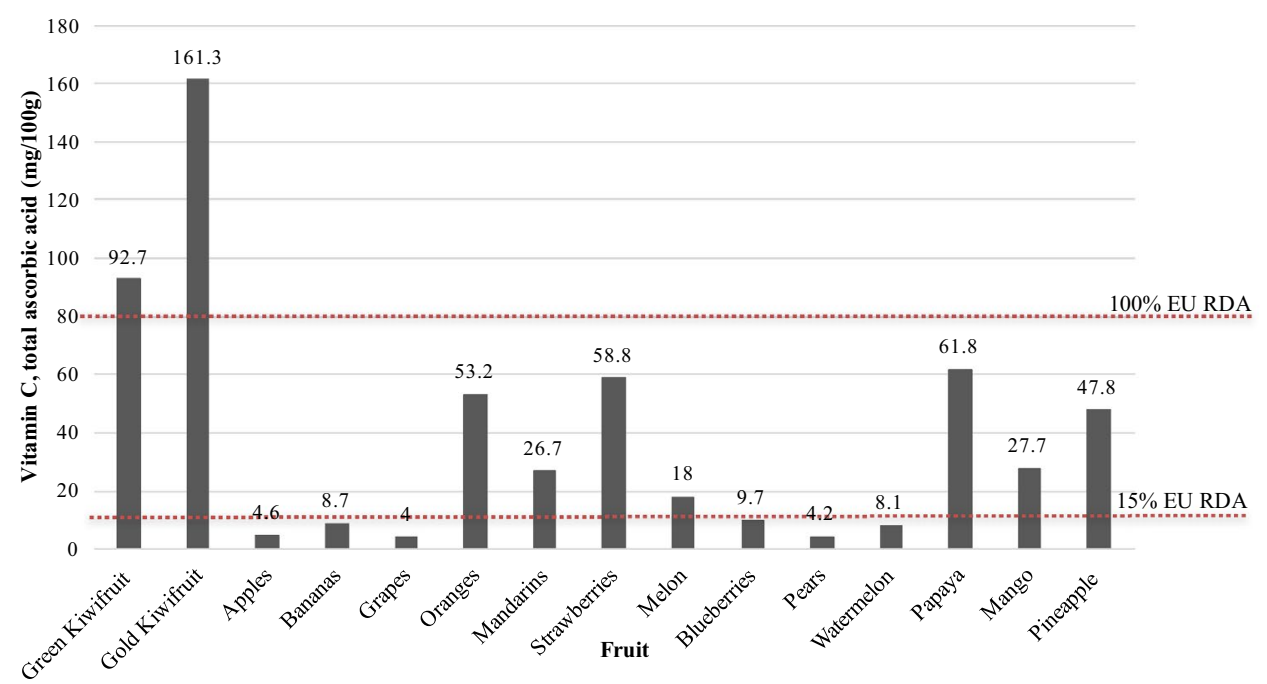


claims are $15 \% \mathrm{RI}$, or $12 \mathrm{mg}$, and $30 \% \mathrm{RI}$, or $24 \mathrm{mg}$, per $100 \mathrm{~g}$, respectively. Hence the levels of vitamin $\mathrm{C}$ in kiwifruit qualify them as being high in the vitamin, and eligible for authorised health claims in the European Union (EU) for vitamin $\mathrm{C}$ nutrient functions (Table 2). Amongst a background of a large number of antioxidant species, the vitamin $\mathrm{C}$ content of kiwifruit has the highest correlation with total antioxidant activity of kiwifruit [34].

High levels of vitamin $\mathrm{C}$ in kiwifruit can improve iron bioavailability [35]. Poor iron status remains one of the most common micronutrient concerns globally [36], and is associated with a number of adverse health consequences [37]. In a study of individuals with low iron status [serum ferritin $(\mathrm{SF}) \leq 25 \mu \mathrm{g} / \mathrm{L}$ and haemoglobin $(\mathrm{Hb}) \geq 115 \mathrm{~g} / \mathrm{L}$ ], eating kiwifruit with an iron-fortified breakfast cereal was found to improve iron status [35, 38]. In this study, 89 healthy women were randomised to receive iron-fortified breakfast cereal, milk and either two Zespri gold kiwifruit or one banana at breakfast every day for 16 weeks. After 16 weeks, median serum ferritin significantly increased from $17.0 \mu \mathrm{g} / \mathrm{L}$ at baseline to $25.0 \mu \mathrm{g} / \mathrm{L}$, compared to the banana group, which had a median serum ferritin level of $16.5 \mu \mathrm{g} / \mathrm{L}$ at baseline that rose to $17.5 \mu \mathrm{g} / \mathrm{L}$ at the end of the study $(P<0.001)$. Importantly, the $10 \mu \mathrm{g} / \mathrm{L}$ increase in serum ferritin in the women who ate kiwifruit increased levels to within the normal reference range of 20-160 mg/L. Additionally, median soluble transferrin receptor concentrations significantly decreased by $-0.5 \mathrm{mg} / \mathrm{L}$ for kiwifruit versus $0.0 \mathrm{mg} / \mathrm{L}$ for banana $(P=0.001)[35,38]$.

Significant proportions of the population around the world, including the UK [39], have very poor fruit and vegetable intakes that result in suboptimal vitamin $\mathrm{C}$ status. The maintenance of the body pools and of plasma and cellular vitamin $\mathrm{C}$ concentrations are considered criteria for establishing the requirements for vitamin $\mathrm{C}$ based on the assumption that saturation of body pools and plasma concentrations are associated with fulfilling the essential functions of vitamin $\mathrm{C}$ in the body [26]. Saturating
Table 2 Summary of wellestablished functions of selected vitamins and minerals under Article 13.1 of the Nutrition and Health Claims Regulation (European Commission 2006) and the proposed wording as shown on the EU Register

\begin{tabular}{|c|c|}
\hline Nutrients & Health claims \\
\hline Vitamin C & $\begin{array}{l}\text { Vitamin C contributes to normal collagen formation for the normal } \\
\text { function of blood vessels } \\
\text { Vitamin } C \text { contributes to normal collagen formation for the normal } \\
\text { function of bones } \\
\text { Vitamin } C \text { contributes to normal collagen formation for the normal } \\
\text { function of cartilage } \\
\text { Vitamin } C \text { contributes to normal collagen formation for the normal } \\
\text { function of gums } \\
\text { Vitamin } C \text { contributes to normal collagen formation for the normal } \\
\text { function of skin } \\
\text { Vitamin } C \text { contributes to normal collagen formation for the normal } \\
\text { function of teeth } \\
\text { Vitamin C contributes to normal energy-yielding metabolism } \\
\text { Vitamin C contributes to normal functioning of the nervous system } \\
\text { Vitamin C contributes to normal psychological function } \\
\text { Vitamin C contributes to normal function of the immune system } \\
\text { Vitamin C contributes to the protection of cells from oxidative stress } \\
\text { Vitamin C contributes to the reduction of tiredness and fatigue } \\
\text { Vitamin C contributes to the regeneration of the reduced form of } \\
\text { vitamin } E \\
\text { Vitamin C increases iron absorption } \\
\text { Vitamin C contributes to maintain the normal function of the } \\
\text { immune system during and after intense physical exercise } \\
\text { (> } 200 \mathrm{mg} \text { /day) }\end{array}$ \\
\hline Vitamin E & Vitamin E contributes to the protection of cells from oxidative stress \\
\hline Folate & $\begin{array}{l}\text { Folate contributes to maternal tissue growth during pregnancy } \\
\text { Folate contributes to normal amino acid synthesis } \\
\text { Folate contributes to normal blood formation } \\
\text { Folate contributes to normal homocysteine metabolism } \\
\text { Folate contributes to normal psychological function } \\
\text { Folate contributes to the normal function of the immune system } \\
\text { Folate contributes to the reduction of tiredness and fatigue } \\
\text { Folate has a role in the process of cell division }\end{array}$ \\
\hline Potassium & $\begin{array}{l}\text { Potassium contributes to normal functioning of the nervous system } \\
\text { Potassium contributes to normal muscle function } \\
\text { Potassium contributes to the maintenance of normal blood pressure }\end{array}$ \\
\hline
\end{tabular}


plasma levels, now considered to be associated with optimal health and wellbeing, are found in only around 20\% of the normal, healthy population. Carr et al. [40] showed that consuming kiwifruit had a strong effect on plasma and muscle [23] vitamin $\mathrm{C}$ levels. To measure the contribution of gold kiwifruit to dietary vitamin $\mathrm{C}$ intake, plasma vitamin $\mathrm{C}$ levels were measured in a group of 14 male students with low vitamin $\mathrm{C}$ status (average baseline plasma, $38 \mathrm{mM}$ ). Participants were asked to consume half a kiwifruit per day for 4 weeks, two kiwifruit per day for 6 weeks and finally three kiwifruit per day for 4 weeks. The addition of as little as half a kiwifruit per day resulted in a significant increase in plasma vitamin C. However, one kiwifruit per day was required to reach what are considered to be healthy levels [40]. At two kiwifruit per day, plasma levels approached saturation, with no further increases with three kiwifruit per day. This observation was confirmed by increased urinary output of vitamin $\mathrm{C}$ at two kiwifruit per day, which coincided with plasma levels reaching around $60 \mathrm{mM}$. These results confirmed the pharmacokinetic data of Levine et al. [41] and indicated that plasma vitamin $\mathrm{C}$ levels in humans saturate at an intake of about $200 \mathrm{mg} / \mathrm{day}$. This is equivalent to eating approximately two kiwifruit per day.

Furthermore, vitamin $\mathrm{C}$ and increased consumption of fruits and vegetables have been shown to be associated with enhanced feelings of wellbeing and vitality [42-45]. It is well established that fatigue and lethargy are common early symptoms of subclinical vitamin $\mathrm{C}$ deficiency and can be resolved with vitamin $C$ supplementation [46]. The effects of vitamin $\mathrm{C}$ on fatigue are likely explained by its in vivo function as an enzyme cofactor for the synthesis of important biomolecules such a dopamine, neurotransmitters and hormones synthesised by the nervous system and adrenal glands [47].

\section{Vitamin E}

Kiwifruit contain relatively high levels of vitamin E [12, 48], compared to other commonly consumed fruit. SunGold and green kiwifruit contain 1.40 and $1.46 \mathrm{mg}$ per $100 \mathrm{~g}$ [11], respectively, of the main form, $\alpha$-tocopherol present in the flesh [49]. These levels are sufficient to permit the use of nutrient function claims for Vitamins E in the EU (Table 2). Fiorentino et al. [49] showed that $\alpha$-tocopherol is found in the flesh of kiwifruit, possibly associated with cell membranes and therefore potentially bioavailable. Fiorentino et al. [49], also identified a new form of vitamin $E$ in kiwifruit, $\delta$-tocomonoenol, noting that its radical scavenging and antioxidant capacity contributed to the total antioxidant activity of kiwifruit. Studies showing that the consumption of both green and gold kiwifruit correlates with increased plasma vitamin $E$ concentrations, suggest the vitamin $E$ in kiwifruit is bioavailable $[31,50]$.

\section{Folate}

Kiwifruit are often referred to as being a good source of dietary folate. The folate content of kiwifruit green and gold cultivars compared with other fruits are shown in Fig. 2. The folate content of $31 \mu \mathrm{g}$ per $100 \mathrm{~g}$ in gold kiwifruit meets the criteria of EU Regulation to make a "source" claim as it exceeds the $15 \%$ of the Reference Intake of $200 \mu \mathrm{g} /$ day. In other countries, where the recommended daily intake is often higher (e.g., 400-500 $\mu \mathrm{g} /$ day in Nordic counties, $400-600 \mu \mathrm{g} /$ day in the USA Australia and NZ), such nutrient content claims cannot be made. The authorised health claims in the EU for folate nutrient functions are shown in Table 2.

As folate is extremely labile and its presence in green leafy vegetables is easily destroyed by cooking, fresh kiwifruit can make a useful contribution to the total diet,
Fig. 2 Graph comparing the folate content of kiwifruit with other commonly consumed fruit

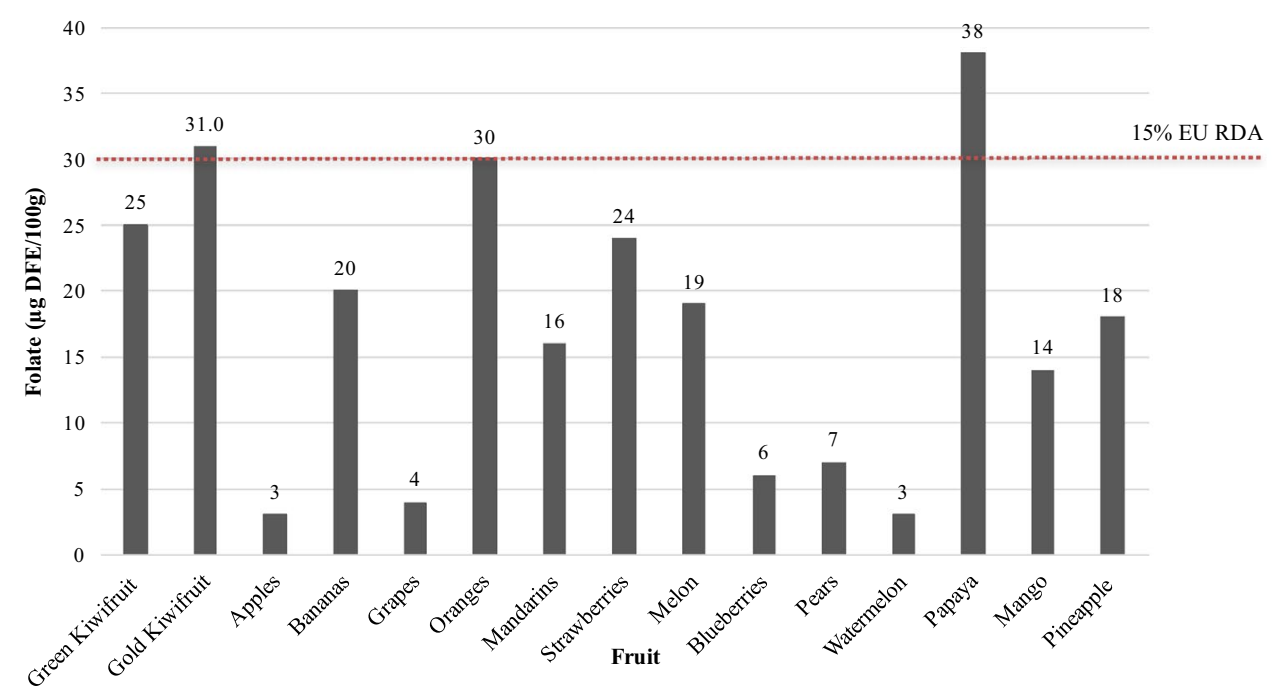


especially during pregnancy when it is difficult to meet folate requirements. During pregnancy, folate requirements are $600 \mu \mathrm{g} / \mathrm{day}$, which can be safely achieved through the use of conventional foods, foods with added nutrients and food supplements [51].

\section{Potassium}

Green and gold kiwifruit are good sources of potassium, containing typically around $301-315 \mathrm{mg}$ per $100 \mathrm{~g}$. These amounts are sufficient to meet the criteria of EU Regulation (EC) no. 1924/2006 on nutrition and health claims made on foods to make a natural "source" claim, as it exceeds the $15 \%$ of the Reference Intake of $2000 \mathrm{mg} /$ day. The authorised nutrient function health claims in the EU for potassium are shown in Table 2. The potassium content of kiwifruit compared to other fruit is shown in Fig. 3. In other countries, where the recommended daily intake is often higher, such content claims cannot be made.

Fresh foods such as fruits and green vegetables are generally good sources of potassium and low in sodium. The sodium content of kiwifruit is only $3 \mathrm{mg}$ per $100 \mathrm{~g}$ and can be described as naturally low in sodium. The sodium to potassium $\left(\mathrm{Na}^{+} / \mathrm{K}^{+}\right)$ratio of kiwifruit is consistent with recommendations to increase potassium intake through increased consumption of fruit and vegetables, and is amongst the more favourable $\mathrm{Na}^{+} / \mathrm{K}^{+}$balance of selected fruits [52]. Studies have provided evidence that potassium rich diets or interventions with potassium can lower blood pressure, especially in individuals with hypertension [53, 54], however, more recently the dietary $\mathrm{Na}^{+} / \mathrm{K}^{+}$ratio has been shown to be more strongly associated with an increased risk of hypertension and CVD-related mortality than the risk associated with either sodium or potassium alone $[55,56]$.

\section{Dietary fibre}

The dietary fibre of kiwifruit comes almost entirely from the plant cell walls, and particularly the polysaccharides that form the major structural components of these walls. Kiwifruit contain about $2-3 \%$ of fresh weight non-starch polysaccharides [48] that make up the fruit cell walls, providing a valuable contribution of both soluble and insoluble fibre to the diet. Analysis of dietary fibre of green and gold kiwifruit has shown they comprise about one-third soluble and two-thirds insoluble fibres, although kiwi gold fruit contain considerably less total fibre than green [57]. The soluble fibre fraction contains almost exclusively pectic polysaccharides, whereas the insoluble fibre is mostly cellulose and hemicelluloses.

Changes occur in the composition and structure of kiwifruit cell walls during development and ripening. These structural changes in cell wall polysaccharides are reviewed in detail by Sims, Monro [58]. Cell wall polysaccharides are generally resistant to digestion and absorption in the human small intestine and are considered to be delivered to the colon in a chemically unaltered state. However, even minor chemical or structural changes can impact on the physicochemical properties and fermentability that determine their impact on health.

In the hind-gut, the physiological benefits of fibre are believed to arise from the products of bacterial fermentation of the soluble fibre, and from the physicochemical properties of any fibre that remains unfermented [59, 60]. Among the most important physicochemical properties of kiwifruit fibres are the hydration properties, which include water retention, capacity and swelling, viscosity (which requires solubility), and properties that depend on the size, shape and porosity of undigested particles. Water retention is physiologically relevant because it influences transit time, faecal
Fig. 3 Graph comparing the potassium content of kiwifruit with other commonly consumed fruit

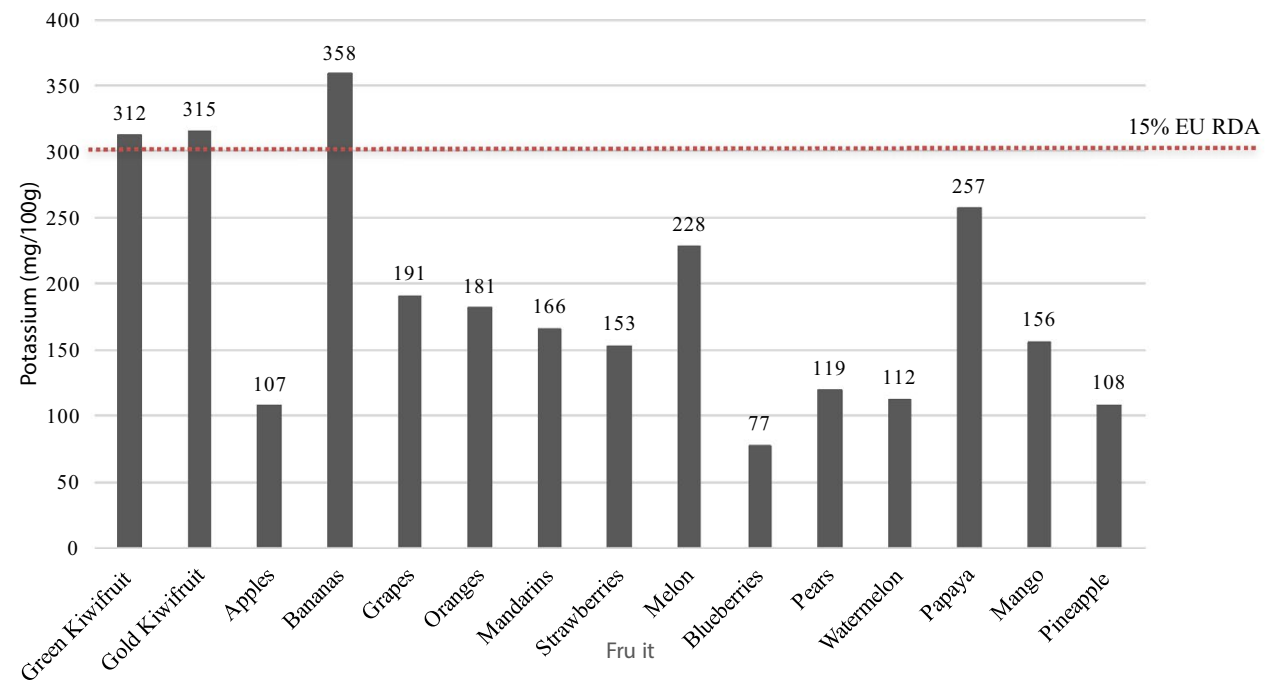


bulk, stool consistency and other functional benefits [60]. The high swelling and water retention of kiwifruit fibre in comparison with other forms of dietary fibre such as wheat bran, commercial preparations of sugar beet fibre and apple fibre, accentuate the value of consuming kiwifruit as a natural whole product that has had minimal processing. Kiwifruit dietary fibres are susceptible to fermentation, and so many provide benefits through the production of the short chain fatty acids [58]. Future studies on the mechanisms by which kiwifruit dietary fibres, as part of a balanced diet, modulate digestion processes and act as a substrate for beneficial colonic microbiota, may aid understanding of the actions of fibre in the gut [61] and its beneficial effects on human health.

\section{Sugars}

As kiwifruit develop and ripen, the concentrations of chemical components in the tissue change. The most marked change in the physiology of the fruit during ripening leads to a rapid decrease in starch concentration and a consequent increase in fructose and glucose. Kiwifruit tissue is very hard while the fruit is developing on the vine, but flesh firmness decreases during the later stages of development [14]. Fortunately, kiwifruit that are physiologically mature but have barely started to ripen can be harvested and will continue to ripen successfully off the vine. Cool storage immediately after harvest reduces the rate of ripening. It is these particular characteristics of kiwifruit that allow producing countries such as New Zealand to store unripe fruit and ship to it distant markets over an extended period. Suitable indicators of maturity for kiwifruit are used to ensure that fruit reaches an appropriate stage of development before harvest. A "maturity value" is important, and three changes in kiwifruit are taken into account-decreasing flesh firmness, conversion of starch to sugar and soluble solids concentration (to measure sugar concentration) are all used to provide an accurate assessment of final eating quality. The predominant sugars present in Actinidia are glucose and fructose with a small amount of sucrose present when the fruit is ripe and ready-to-eat. The amount of total sugars and ratios of these sugars vary not only as a function of maturity but also with the variety of kiwifruit $[62,63]$. The ratio of fructose: glucose is important in terms of digestive health and preferably should be around 1:1 to reduce symptoms of gastrointestinal discomfort, such as bloating, caused by rapid fermentation by gut bacteria.

Interestingly, as they ripen, many fruits undergo a marked decrease in chlorophyll content, and carotenoids and anthocyanins become dominant. These visual changes indicate the stage of ripeness. On the other hand, in green kiwifruit there is little if any decrease in chlorophyll content and the internal colour remains an attractive bright green when fruit are "eating ripe". As kiwifruit begins to ripen, starch concentration decreases from $6 \%$ of fresh weight to trace amounts, and total sugars increase to $12-15 \%$. The concentration of soluble solids also increases to reach a plateau of $14-16 \%$ before fruit is eating ripe.

Understanding the factors affecting the rate of ripening is of considerable commercial importance for fruit quality. In fruit that is ready for consumption the sugars provide the appealing sweet flavour of kiwifruit, which is balanced by the organic acid composition [62, 63].

From a physiological perspective, the sugar content of kiwifruit, like all fruit, may potentially influence the management of blood sugar levels following their consumption, however current research suggests the glycaemic response effects of kiwifruit as a whole food are potentially different to that which could be expected of individual components [64]. Interestingly the glycaemic index (GI) of kiwifruit is relatively low (green kiwifruit, $39.3 \pm 4.8$ and gold kiwifruit, $48.5 \pm 3.1$ [65]). The low GI value of kiwifruit is observed in both healthy human subjects and those with Type 2 diabetes [66]. The importance of managing postprandial blood sugar levels is covered in the section on metabolic health.

\section{Antioxidants}

In addition to the various nutrients in kiwifruit described above, for which there are dietary intake recommendations and well described physiological functions, kiwifruit contain a complex network of minor compounds that may also be associated with beneficial physiological functions. Various Actinidia species have been extensively analysed for their antioxidant chemical profiles [67-71]. As well as vitamins C and $\mathrm{E}$, the other antioxidants include the carotenoids lutein, zeaxanthin and $\beta$-carotene, chlorophylls, quinic acid, caffeic acid glucosyl derivatives, $\beta$-sitosterol, chlorogenic acid, phenolics, including flavones and flavonones, to name but a few [72-75]. The antioxidant capacity of kiwifruit constituents has been measured by means of various in vitro chemical assays that monitor the quenching, scavenging or retarding of free radical generation [6]. For example, the total antioxidant capacity of kiwifruit was reported to be higher than apple, grapefruit and pear, but less than raspberry, strawberry, orange and plum $[76,77]$. While these in vitro studies indicate that the various antioxidants are capable of preventing or delaying some types of cell damage from the unstable free radicals created every day during normal metabolism, the detailed mechanism of how this translates to effects in vivo which are directly linked physiological changes is yet to be fully understood [78]. In a number of human studies, beneficial changes to biomarkers of CVD, have been attributed to the antioxidant compounds present in kiwifruit [79-85]. The stability of antioxidants during simulated in vitro gastrointestinal digestion [86, 87], 
and their bioaccessibility/bioavailability [88] provide supportive evidence for the potential for physiological effects of the antioxidants in kiwifruit. There is significant variation in the types and levels of antioxidant compounds and total antioxidant activity both between Actinidia species, and as a function of extraction solvent [73-75]. Several studies have explored the influence of growing practices and region on the activity of bioactive and antioxidant compounds in kiwifruit. Park et al. [89] found generally higher, but not consistently significant, levels of bioactive compounds in organically grown kiwifruit, whilst in an Italian study, the geographical location of orchards did not significantly influence vitamin C or polyphenolic contents [90].

Although there are no dietary intake recommendations for antioxidants in general, the scientific data suggest that eating kiwifruit has the potential to inhibit oxidative and inflammatory processes, although the supporting data for antioxidant activities are more substantial than those related to the kiwifruit's potential anti-inflammatory activities. The results of human studies of the antioxidant efficacy of kiwifruit are inconsistent owing to differences in experimental protocols, the cultivar of kiwifruit used, the amount and duration of the study as well as the biomarkers used [6]. Kiwifruit could undoubtedly be a useful dietary vehicle for delivering antioxidant nutrients and other phytonutrients. Future studies on kiwifruit will explore the bioavailability, metabolism, tissue distribution and biological effects of kiwifruit constituents on relevant disease markers. The emerging evidence could provide the basis for improved dietary strategies for achieving dietary antioxidant and anti-inflammatory health benefits in humans [91].

\section{Actinidin and minor proteins}

Kiwifruit contain several unique proteins and the cysteine protease actinidin, the most abundant protein in kiwifruit, of interest for their bioactive potential.

The characterisation and biochemical properties of actinidin have been extensively studied [92, 93], and more recently its potential role in human health [94, 95]. Actinidin is active over a wide range of $\mathrm{pH}$, including those of the GI tract [96] thus having the potential to influence protein digestion, and intestinal permeability [97]. In contrast to potential benefits (see Digestive health), actinidin is also the major kiwifruit allergen [90, 98]. Green and gold kiwifruit have been known to cause allergic reactions ranging from mild symptoms localised to the oral mucosa in the majority of individuals to anaphylactic reactions, particularly in children [99]. Very little information is available in the literature on the prevalence of kiwifruit allergy, and human intervention studies with kiwifruit have shown that kiwifruit are well tolerated without any adverse side effects $[35,50,84$, 100]. The magnitude and patterns of reactivity to kiwifruit allergens appears to vary with ethnic/geographical/cultural differences, age of subjects and other clinical characteristics of individuals exposed to kiwifruit [6]. Lucas, Atkinson [101] have provided a detailed review of unresolved issues regarding kiwifruit and have suggested requirements to be met prior to designation of allergens to a database. Processing may diminish the risk of allergic symptoms in those with allergies to raw kiwifruit $[102,103]$.

Kiwellin is another protein in kiwifruit, that as a function of ripening stage and postharvest treatment of the fruit is susceptible to actinidin activity, producing the peptide kissper, and and KiTH [104, 105]. Kissper is of particular interest for human health as it displays a range of beneficial activities, including anti-inflammatory response, reducing oxidative stress at the GI mucosal interface [106], and $\mathrm{pH}$ dependent and voltage-gated pore-forming activity, together with anion selectivity and channelling [4]. This suggests that kissper is a member of a new class of pore-forming peptides with potential beneficial effects on human health, including a potential effect on gastrointestinal physiology [4].

\section{Digestive health}

Early Chinese pharmacopoeia from the Tang Dynasty onwards (AD 618-907) list a whole variety of medicinal uses for "mihoutao" fruit, the Chinese name generally used for Actinidia species, including aiding digestion, reduction of irritability and curing of dyspepsia and vomiting.

Functional gastrointestinal disorders (FGIDs) are common and distressing [107]. FGIDs include functional dyspepsia (FD) and irritable bowel syndrome (IBS), affecting an estimated 3-28\% of the global population [108], particularly the elderly and women, and may severely affect the individual's quality of life and wellbeing [107, 109]. Upper gastrointestinal disorders include gastric reflux, stomach ache, delayed gastric emptying, nausea and vomiting, and lower gastrointestinal disorders include constipation, indigestion, bloating and diarrhoea. Current interventions for FGIDs include lifestyle and dietary modifications as well as pharmacological interventions targeting pain, motility, laxation and the gut microbiota [108].

The worldwide growth in the incidence of FGIDs has created an immediate need to identify safe and effective food-based interventions. For example, constipation may be present in up to $29 \%$ of the population, depending on the definitions used [110-112]. Food ingredients such as psyllium and wheat bran are the most studied for maintaining a healthy gut and to manage abdominal discomfort. Additionally, it is generally regarded that adequate intakes of fibrerich fruits and vegetables daily with sufficient water will prevent constipation. Whole green kiwifruit have been used and promoted for many years to maintain abdominal comfort 
[113] and have been studied more recently under controlled settings $[114,115]$. The components found in kiwifruit have been shown to increase faecal bulking and softness and enable better lubrication, assisting the propulsion of content along the colon $[116,117]$.

It is thought that the unique combination of soluble and insoluble fibres, polyphenols and actinidin, present in kiwifruit, confers the gastrointestinal benefits, improvements in laxation and reduction of abdominal discomfort, both in individuals with either constipation-predominant irritable bowel syndrome (IBS-C) and in normal healthy people suffering from constipation without reported side effects. The putative mechanism of kiwifruit on maintenance of normal GI function has recently been reviewed [95]. The review discusses the physiological functions of the digestive system, the pathophysiological mechanisms behind functional constipation, a summary of the work covering the effects of green kiwifruit on the gut as well as hypothetical mechanisms behind the gastrointestinal effects of green kiwifruit.

Lack of dietary fibre is a contributing factor in people with constipation [118], and both soluble and insoluble fibres can add bulk, increase water retention in the colon $[119,120]$ and change faecal consistency $[121,122]$. Dietary fibre can also decrease transit time [122, 123]. Soluble dietary fibres are the main substrate for the microflora in the GI tract [60]. When setting the Dietary Reference Value (DRV) of $25 \mathrm{~g} /$ day for dietary fibre, the EFSA NDA Panel used the role of fibre in bowel function as the most suitable criterion [124]. Consuming 2 green kiwifruit per day would provide approximately $6 \mathrm{~g}$ of fibre (24\% DRV), therefore, depending on habitual dietary fibre intake this may be a significant contribution to the total daily intake. Kiwifruit typically contain about two-thirds insoluble fibre, and one-third soluble fibre [125], and as previously mentioned, kiwifruit fibre has an impressive water retention capacity $[57,58]$. In the native state, the capacity of kiwifruit fibre to swell, defined as the volume fibre has in water after passively settling [126], is more than six times higher than that of apple fibre, and one and a half times higher than psyllium [58], but is significantly reduced when subjected to processing conditions such as dehydration [127]. Feeding studies in pigs [128, 129] as well as observations in human studies $[114,115,130]$ have demonstrated that feeding kiwifruit increases water retention and faecal bulking, however animal studies suggest the pectic substances of kiwifruit are highly susceptible to fermentation in the hind-gut $[131,132]$. Such fermentation may produce short-chain fatty acids capable of stimulating colonic motility [133] and contribute to the effects of kiwifruit, however the role of kiwifruit fibre in human digestive function is yet to be fully understood. In contrast, but consistent with earlier findings of changes associated with processed kiwifruit, the fibre of a dried kiwifruit product consumed as a part of a mixed fibre diet, did not demonstrate a significant contribution to faecal bulking in the rat [131]. A reduction in GI transit time has been linked to actinidin [128]. Although a considerable proportion of short chain fatty acids have recently been shown to be derived from the fermentation of non-dietary gut materials [134], kiwifruit fibre may also contribute to favourable changes in the human colonic microbial community [135] and their metabolites [136] which are associated with intestinal health [137].

The proteolytic enzyme actinidin from green kiwifruit has been shown in in vitro studies to aid protein digestion both in the stomach and small intestine [2, 3]. For example, a range of common protein sources derived from soy, meat, milk and cereals were incubated with a kiwifruit extract containing actinidin and pepsin at $\mathrm{pH} 1.9$ (a simulation of gastric digestion in humans) [3]. Results in this gastric digestion model showed that for milk, soy and meat protein sources, the presence of kiwifruit extract enhanced digestion to a greater extent than pepsin alone [13]. Likewise, in an in vitro, small intestine digestion model, actinidin-containing kiwifruit extract was particularly effective in improving the digestion of whey protein, zein, gluten and gliadin [2]. These studies suggest that actinidin may assist with protein digestion in the gastric and ileal regions, that may be of benefit particularly to individuals with compromised digestive function [138]. Under in vitro conditions, gastric lipase remained active, however actinidin effectively inactivated amylase suggesting that when cooked starch is consumed together with kiwifruit it is possible that starch digestion may be retarded [139].

There is growing evidence that kiwifruit have beneficial effects on digestive health and general wellbeing, a potentially important characteristic in the light of the increasing proportion of the elderly population in ageing societies that experience impaired bowel function, changes in gastrointestinal function [138], and gastrointestinal discomfort.

Table 3 summarises the findings from human clinical trials with fresh green kiwifruit. The daily consumption of two kiwifruit was found to increase stool frequency, including the number of complete spontaneous bowel motions per week, reduce gastrointestinal transit time and improve measures of intestinal comfort. These early human studies [50, $114,130,140-142]$ were carried out in different countries and included different study populations (e.g., differing in age, health status), and the lack of a common protocol may have led to results that were not applicable to the larger normal healthy population. Most studies consider the effects of prolonged kiwifruit consumption, however recently Wallace et al. [143] investigated the acute effects of green kiwifruit on gastric emptying following consumption of a steak meal, using a computerised SmartPill ${ }^{\mathrm{TM}}$, and measures of digestive comfort. Although the SmartPill ${ }^{\mathrm{TM}}$, did not provide reliable data following the meal event, there was a significant reduction in bloating and other measures of gastric discomfort [143]. A multi-country, randomised, cross-over, controlled 
Table 3 Summary of findings from human studies with fresh green kiwifruit for digestive health

\begin{tabular}{|c|c|c|c|c|c|c|c|c|c|}
\hline Study & Country & \begin{tabular}{|l|}
$\begin{array}{l}\text { Population } \\
\text { group }\end{array}$ \\
\end{tabular} & Intervention & $\begin{array}{l}\text { Study } \\
\text { Quality } \\
\text { High } \\
\text { O Low } \\
\text { X Not able } \\
\text { to assess }\end{array}$ & $\begin{array}{l}\text { Frequency } \\
0 \text { १, SS } \\
\bigcirc \uparrow, \text { NSS }\end{array}$ & $\begin{array}{l}\text { Stool form } \\
\mathbf{9} \uparrow, \mathrm{SS} \\
\bigcirc \uparrow, \mathrm{NSS} \\
\mathrm{X} \text { not } \\
\text { measured }\end{array}$ & 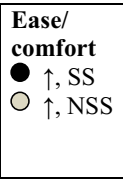 & \begin{tabular}{|l|} 
Transit \\
time \\
$\downarrow \downarrow$, SS \\
$X$ not \\
measured
\end{tabular} & $\begin{array}{l}\text { Side } \\
\text { effects } \\
\text { none }\end{array}$ \\
\hline Chan et al. [131] & China & \begin{tabular}{|l}
$\begin{array}{l}\text { Functional } \\
\text { constipation }\end{array}$ \\
\end{tabular} & $\begin{array}{l}2 \text { kiwifruit } \\
\text { per day }\end{array}$ & & & $\Omega$ & & & \\
\hline Chang et al. [115] & Taiwan & IBS-C & $\begin{array}{l}2 \text { kiwifruit } \\
\text { per day }\end{array}$ & ) & & $\mathrm{X}$ & D & & \\
\hline Hiele [141] & Belgium & $\begin{array}{l}\begin{array}{l}\text { Functional } \\
\text { constipation }\end{array} \\
\end{array}$ & $\begin{array}{c}3 \text { kiwifruit } \\
\text { per day }\end{array}$ & 0 & & & & $\mathrm{X}$ & \\
\hline $\begin{array}{l}\text { Cunillera et al. } \\
{[142]}\end{array}$ & Spain & $\begin{array}{l}\text { Functional } \\
\text { constipation }\end{array}$ & $\begin{array}{l}3 \text { kiwifruit } \\
\text { per day }\end{array}$ & & & & & $\mathrm{X}$ & \\
\hline Ohsawa et al. [143] & Japan & $\begin{array}{l}\text { Prone to } \\
\text { constipation }\end{array}$ & $\begin{array}{l}2 \text { kiwifruit } \\
\text { per day }\end{array}$ & & & & & $\mathrm{X}$ & \\
\hline $\begin{array}{l}\text { Rush et al. [114] } \\
\text { Pre-trial }\end{array}$ & New Zealand & Healthy & $\begin{array}{l}1 \text { kiwifruit } \\
\text { per } 30 \mathrm{~kg} \\
\text { bodyweight }\end{array}$ & $\mathrm{X}$ & O & & & $\mathrm{X}$ & \\
\hline $\begin{array}{l}\text { Rush et al. [114] } \\
\text { Main trial }\end{array}$ & New Zealand & $\begin{array}{l}\text { Healthy } \\
\text { elderly }\end{array}$ & $\begin{array}{l}1 \text { kiwifruit } \\
\text { per } 30 \mathrm{~kg} \\
\text { bodyweight }\end{array}$ & & & & & $\mathrm{X}$ & \\
\hline
\end{tabular}

human intervention study is currently underway to evaluate further the effects of green kiwifruit on digestive function [144]. Changes in bowel function in the general population such as reduced transit time, more frequent bowel movements, increase faecal bulk or softer stools are considered by EFSA to be beneficial physiological effects, provided they do not result in diarrhoea [32]. Similarly, reducing gastrointestinal discomfort [e.g., bloating, abdominal pain/cramps, borborygmi (rumbling)] are considered appropriate outcome measures in human studies that include the use of validated questionnaires on severity and frequency of symptoms. The EFSA Panel on Dietetic Products Nutrition and Allergies (NDA) [32] has also stated that IBS patients or subgroups of IBS are generally considered an appropriate study group to substantiate health benefits on bowel function and GI discomfort.

Fermentable Oligosaccharides, Disaccharides, Monosaccharides and Polyols (FODMAPs) are rapidly fermentable, poorly absorbed carbohydrates found in food that can cause digestive discomfort, especially for people with IBS [145]. The action of FODMAPS is likely via multiple pathways [146], and includes the release of gases from the bacterial fermentation of oligosaccharides and the proportion (if any) of malabsorbed fructose, polyols, and lactose [147]. Symptoms associated with FODMAPs include abdominal bloating, pain, cramps, excessive flatulence and altered bowel habit [146]. Low FODMAP diets are effective in the treatment of functional gastrointestinal symptoms [148, 149].

Kiwifruit are certified as low FODMAP fruits by the Monash University low-FODMAP diet digital application (https://www.monashfodmap.com/i-have-ibs/get-the-app/), based on their relatively low proportions of fructose and fructans per single fruit serve. A recent pilot study demonstrated that the consumption of two green kiwifruit is not associated with clinically significant evidence of colonic fermentation as shown by hydrogen and methane on breath testing [150], lending support for the low FODMAP status for kiwifruit.

\section{Metabolic health}

Metabolic abnormalities such as dyslipidaemia [increased blood total cholesterol (TC), low density lipoprotein cholesterol (LDL-C), triglycerides (TG), lower high density lipoprotein cholesterol (HDL-C)], hypertension, vascular inflammation, abnormal glucose metabolism and haemostatic disorders all play important roles in the pathophysiology of the major causes of morbidity and mortality such as diabetes, cardiovascular disease (CVD), stroke and dementia [151-153]. A number of studies have investigated the effects of green and gold kiwifruit on some of these metabolic markers, including the effects of kiwifruit on glucose and insulin balance, and on bodyweight maintenance and energy homeostasis.

Green and gold kiwifruit have clinically measured glycaemic indices (GIs) of 39 and 48, respectively [65], which puts them in the GI "low" category $(\mathrm{GI}<55)$. The glycaemic response to a fruit depends not only on GI, but also the amount of carbohydrate consumed in the fruit. As kiwifruit contains only about $12 \%$ available carbohydrate and a low GI; the impact kiwifruit produces on plasma glucose levels is low enough for the fruit to be suitable in managing diets for people with reduced tolerance to glucose. The fibre content of kiwifruit may cause a delay in carbohydrate digestion and absorption by way of swelling action that reduces the rate of glucose diffusion $[57,127]$. This reduction in glycaemic response by $200 \mathrm{~g}$ kiwifruit (approximately two fruits) has been demonstrated in a human intervention study conducted by Mishra et al. [154]. The authors concluded that 
the low in vivo glycaemic impact could partly be attributed to the carbohydrate in kiwifruit being fruit sugars (fructose) and partly to the non-digested fibre components reducing the rate of intestinal processes such as digestion, sugar diffusion and mixing of intestinal contents. This partial substitution of starch-based staple foods, such as a high carbohydrate breakfast cereal, with kiwifruit could be an effective and healthy way to improve glucose homeostasis [154]. Further exploration of this effect was investigated by Mishra et al. [64] to better understand the role of non-sugar components in kiwifruit in modulating glycaemic response. Kiwifruit consistently reduced the amplitude of the glycaemic response of participants following a series of wheat-based cereal meals adjusted to match the available carbohydrates from kiwifruit leading the investigators to conclude that components other than the available carbohydrate in kiwifruit, such as cell wall remnants or phenolic compounds, may be involved in the improved glycaemic response to co-ingested foods [64]. The energy value of foods is also an important dietary aspect in managing risk factors for metabolic syndrome. Using an in vivo-in vitro model that determines the available energy (AE) content based on ATP yield at the cellular level [155], Henare et al. [156] found the AE of green and gold kiwifruit was significantly less than that predicted by the traditional Atwater system, suggesting kiwifruit are useful in dietary weight management strategies. Further studies will explore the use of kiwifruit as an effective dietary strategy to reduce postprandial hyperglycaemia while at the same time increasing the amount of essential nutrients consumed.

Regular consumption of green and gold kiwifruit can also affect beneficially certain physiological biomarkers, particularly in individuals with metabolic abnormalities related to major causes of morbidity and mortality, such as diabetes, cardiovascular disease (CVD), stroke and dementia [157]. For example, Chang, Liu [158] investigated the effects of two kiwifruits on the lipid profile, antioxidants and markers of lipid peroxidation in hyperlipidaemic adult men and women in Taiwan. After 8 weeks of the intervention, the HDL-C concentration was significantly increased, whilst the LDL-C/HDL-C ratio and TC/HDL-C ratio were significantly decreased. Vitamin $\mathrm{C}$ and vitamin $\mathrm{E}$, the antioxidant nutrients, together with plasma antioxidant status, also increased significantly in fasting blood samples.

Gammon et al. [100] found that consumption of two green kiwifruit per day for 4 weeks favourably affects plasma lipids in a randomised controlled trial in 85 normotensive and prehypertensive hypercholesterolaemic men compared with the consumption of a healthy diet alone. Small, but significant, differences occurred, including an increase in HDL-C and a decrease in TC: HDL-C ratio and TG's. There were no significant differences, however, between the two interventions for plasma TC, LDL-C, insulin, high-sensitivity C-reactive protein (hs-CRP), glucose and blood pressure (BP). In a further exploration of the study, no beneficial effects on markers of cardiovascular function, or on BP were noted [159].

In 2012, Karlsen et al. [80] demonstrated that intake of three kiwifruit per day for 3 weeks promoted pronounced anti-hypertensive effects, as well as antithrombotic effects in male, middle-aged and elderly smokers. The authors commented that this dietary approach may be helpful in postponing pharmacological treatment in individuals with high-normal blood pressure or hypertension. From a further randomised, controlled study over a period of 8 weeks, Svendsen et al. [79] concluded that among men and women aged between 35 and 69 years with moderately elevated BP, the intake of 3 kiwifruit added to the usual diet was associated with lower systolic and diastolic 24-h BP compared with one apple a day. The authors observed these results were in contrast those of Gammon et al. [159], noting the differences in study population criteria (normotensive [159] versus moderately elevated BP [79]) may have been a contributory factor. Although Svendsen et al. [79] found no differences in measures of endothelial function in their study, they suggested that an increase in plasma antioxidant status (lutein), and in increased dietary potassium, resulting from the kiwifruit intervention, could be an explanation for the improvements in BP observed.

In vitro studies on antioxidant and fibrinolytic activities have also indicated the potential cardiovascular protective properties of kiwifruit extracts [160]. Evidence that consumption of kiwifruit can modulate platelet reactivity towards collagen and ADP in human volunteers was provided in a study by Duttaroy, Jørgensen [84]. The authors concluded that kiwifruit may have the potential to increase the effectiveness of thrombosis prophylaxis.

Habitual intakes of high levels of fruits and vegetables have long been associated with beneficial effects that lower the risk of chronic diseases, including CVD in humans [161]. The presence of antioxidant components such as vita$\min \mathrm{C}$, vitamin E, polyphenols [162], a favourable $\mathrm{Na}^{+} / \mathrm{K}^{+}$ ratio [52], and other bioactive components in kiwifruit could explain their beneficial physiological effects [157].

\section{Concluding remarks}

This review highlights the nutritional attributes and health benefits of green and gold kiwifruit. The nutritional composition, particularly the high amount of vitamin C, supports its position as a highly nutritious, low energy fruit. With the plethora of man-made, processed health foods available to the consumer, one aspect that sets kiwifruit apart is that it is a natural, whole food. Nature compartmentalises many bioactive and nutritional components within the complex structure of cell walls, cells and the matrix in between. Human 
digestion interacts with fresh whole foods to break down the structures and digests the complex carbohydrates slowly. Many health care professionals now recognise whole foods are ideal for the release and delivery of nutrients and health components to various locations along our digestive tract.

There is a growing body of evidence to support the beneficial effects of kiwifruit in gastrointestinal function in healthy individuals as well as in individuals with constipation and other gastrointestinal disorders [143, 144, 163], and recognition for the role of kiwifruit in their management [164]. This presents an evidence-based opportunity for health care professionals to adopt dietary recommendations, and for consumers to recognise the impact of diet, in particular whole foods, on specific body function, and their health and well-being. Green and gold kiwifruit are well characterised and the mechanisms of action for the benefits on gastrointestinal function and modulation of glycaemic responses now being better defined.

Overall, the scientific evidence for the health benefits of kiwifruit needs to be expanded through the conduct of well-designed and executed human intervention studies that clearly define the study populations, the amount and duration of kiwifruit consumption and the specific beneficial physiological effects. A greater understanding of the mechanisms of action of kiwifruit and its bioactive constituents in promoting health also needs to be fully elucidated.

The increased research data identifying the nutritional and health benefits of kiwifruit and their growing consumer acceptance as a part of a balanced diet, will undoubtedly offer opportunities to tackle some of the major health and wellness concerns around the world.

Acknowledgements Funding for this review was provided by Zespri International Ltd, Mount Maunganui, New Zealand.

\section{Compliance with ethical standards}

Conflict of interest DPR and LND have served on advisory boards and been paid to undertake and present work on behalf of Zespri International Ltd. JA is an employee of Zespri International Ltd.

Open Access This article is distributed under the terms of the Creative Commons Attribution 4.0 International License (http://creativeco mmons.org/licenses/by/4.0/), which permits unrestricted use, distribution, and reproduction in any medium, provided you give appropriate credit to the original author(s) and the source, provide a link to the Creative Commons license, and indicate if changes were made.

\section{References}

1. Boeing H, Bechthold A, Bub A, Ellinger S, Haller D, Kroke A, Leschik-Bonnet E, Müller MJ, Oberritter H, Schulze M, Stehle P, Watzl B (2012) Critical review: vegetables and fruit in the prevention of chronic diseases. Eur J Nutr 51:637-663
2. Kaur L, Rutherfurd SM, Moughan PJ, Drummond L, Boland MJ (2010) Actinidin enhances protein digestion in the small intestine as assessed using an in vitro digestion model. J Agric Food Chem 58(8):5074-5080. https://doi.org/10.1021/jf903835g

3. Kaur L, Rutherfurd SM, Moughan PJ, Drummond L, Boland MJ (2010) Actinidin enhances gastric protein digestion as assessed using an in vitro gastric digestion model. J Agric Food Chem 58(8):5068-5073. https://doi.org/10.1021/jf903332a

4. Ciardiello MA, Meleleo D, Saviano G, Crescenzo R, Carratore V, Camardella L, Gallucci E, Micelli S, Tancredi T, Picone D, Tamburrini M (2008) Kissper, a kiwi fruit peptide with channel-like activity: structural and functional features. J Pept Sci 14(6):742-754. https://doi.org/10.1002/psc.992

5. Nishiyama II (2007) Fruits of the actinidia genus. Adv Food Nutr Res 52:293-324

6. Singletary K (2012) Kiwifruit: overview of the potential health benefits. Nutr Today 47(3):133-147

7. Ward C, Courtney D (2013) Kiwifruit: taking its place in the global fruit bowl. In: Boland M, Moughan PJ (eds) Advances in food and nutrition research: nutritional benefits of kiwifruit, vol 68. Academic Press, pp 1-15

8. Ferguson AR, Bollard E (1990) Domestication of the kiwifruit In: Warrington IJ, Weston GC (eds) Kiwifruit: science and management. Ray Richards in Association with the New Zealand Society of Horticultural Science, Auckland, pp 165-246

9. Ferguson AR, Huang H (2007) Genetic resources of kiwifruit: domestication and breeding. Horticult Rev 33:1-121

10. Vaughan JG, Geissler CA (2009) The New Oxford book of food plants. Oxford University Press, Great Clarendon Street Oxford $\mathrm{X} 26 \mathrm{DP}$

11. US Department of Agriculture (2016) Green Kiwifruit. USDA National Nutrient Database for Standard Reference, Release 28 (slightly revised). Version: May 2016. US Department of Agriculture (USDA), Agricultural Research Service (ARS), Nutrient Data Laboratory, Beltsville (MD). http://www.ars.usda.gov/ba/ bhnrc/ndl

12. Boland MJ (2013) Kiwifruit proteins and enzymes: actinidin and other significant proteins. In: Boland M, Moughan PJ (eds) Advances in food and nutrition research: nutritional benefits of kiwifruit, vol 68. Academic Press, pp 59-80

13. Sivakumaran S, Sivakumaran S (2017) Partial nutritional analysis of Zespri ${ }^{\circledR}$ SunGold kiwifruit skin (HN1745). In: Confidential Report for Zespri International Ltd. Plant and Food Research, Palmerston North

14. Beever DJ, Hopkirk G (1990) Fruit development and fruit physiology. In: Warrington IJ, Weston GC (eds) Kiwifruit: science and management. The New Zealand Society for Horticultural Science and Ray Richards Publisher, Auckland, pp 97-126

15. Lee SK, Kader AA (2000) Preharvest and postharvest factors influencing vitamin $\mathrm{C}$ content of horticultural crops. Postharvest Biol Technol 20:207-220

16. Drewnowski A (2005) Concept of a nutritious food: toward a nutrient density score. Am J Clin Nutr 82(4):721-732

17. Darmon N, Darmon M, Maillot M, Drewnowski A (2005) A nutrient density standard for vegetables and fruits: nutrients per calorie and nutrients per unit cost. J Am Diet Assoc 105(12):1881-1887. https://doi.org/10.1016/j.jada.2005.09.005 doi

18. Drewnowski A (2010) The nutrient rich foods index helps to identify healthy, affordable foods. Am J Clin Nutr 91(4):1095S-1101S. https://doi.org/10.3945/ajen.2010.28450D

19. Nishikimi M, Fukuyama R, Minoshima S, Shimizu N, Yagi K (1994) Cloning and chromosomal mapping of the human nonfunctional gene for L-gulono-gamma-lactone oxidase, the enzyme for L-ascorbic acid biosynthesis missing in man. J Biol Chem 269(18):13685-13688 
20. Englard S, Seifter S (1986) The biochemical functions of ascorbic acid. Annu Rev Nutr 6:365-406. https://doi.org/10.1146/ annurev.nu.06.070186.002053

21. Arrigoni O, De Tullio MC (2002) Ascorbic acid: much more than just an antioxidant. Biochim Biophys Acta 1569(1-3):1-9

22. Massip L, Garand C, Paquet ER, Cogger VC, O'Reilly JN, Tworek L, Hatherell A, Taylor CG, Thorin E, Zahradka P, Le Couteur DG, Lebel M (2009) Vitamin C restores healthy aging in a mouse model for Werner syndrome. FASEB J. https://doi. org/10.1096/fj.09-137133

23. Carr AC, Bozonet SM, Pullar JM, Simcock JW, Vissers MC (2013) Human skeletal muscle ascorbate is highly responsive to changes in vitamin $\mathrm{C}$ intake and plasma concentrations. Am J Clin Nutr 94(4):800-807. https://doi.org/10.3945/ajcn.112.05320 7

24. Carr A, Frei B (1999) Does vitamin C act as a pro-oxidant under physiological conditions? FASEB J Off Publ Fed Am Soc Exp Biol 13 (9):1007-1024

25. Mandl J, Szarka A, Banhegyi G (2009) Vitamin C: update on physiology and pharmacology. Br J Pharmacol 157(7):10971110. https://doi.org/10.1111/j.1476-5381.2009.00282.x

26. German Nutrition Society (DGE) (2015) New reference values for vitamin C intake. Ann Nutr Metab 67(1):13-20. https://doi. org/10.1159/000434757

27. Carr AC, Frei B (1999) Toward a new recommended dietary allowance for vitamin $\mathrm{C}$ based on antioxidant and health effects in humans. Am J Clin Nutr 69(6):1086-1107

28. Vissers MCM, Wilkie RP (2007) Ascorbate deficiency results in impaired neutrophil apoptosis and clearance and is associated with up-regulation of hypoxia-inducible factor 1 alpha\}. J Leukoc Biol 81(5):1236-1244. https://doi.org/10.1189/jlb.0806541

29. Parker A, Cuddihy SL, Son TG, Vissers MC, Winterbourn CC (2011) Roles of superoxide and myeloperoxidase in ascorbate oxidation in stimulated neutrophils and $\mathrm{H}_{2} \mathrm{O}_{2}$-treated HL60 cells. Br J Pharmacol 51(7):1399-1405. https://doi.org/10.1016/j.freer adbiomed.2011.06.029

30. Hemila H, Chalker E (2013) Vitamin C for preventing and treating the common cold. Cochrane Database Syst Rev (1):Cd000980. https://doi.org/10.1002/14651858.CD000980. pub4

31. Hunter DC, Skinner MA, Wolber FM, Booth CL, Loh JMS, Wohlers M, Stevenson LM, Kruger MC (2011) Consumption of gold kiwifruit reduces severity and duration of selected upper respiratory tract infection symptoms and increases plasma vitamin $\mathrm{C}$ concentration in healthy older adults. Br J Nutr 108(7):1235-1245. https://doi.org/10.1017/S0007114511006659

32. EFSA Panel on Dietetic Products Nutrition and Allergies (NDA) (2016) Guidance on the scientific requirements for health claims related to the immune system, the gastrointestinal tract and defence against pathogenic microorganisms. EFSA J 14 (1):4369. https://doi.org/10.2903/j.efsa.2016.4369

33. European Commission (2011) Regulation (EU) no. 1169/2011, Provision of Food Information to Consumers. Official Journal of the European Union L 304/18

34. Lim YJ, Oh C-S, Park Y-D, Eom SH, Kim D-O, Kim U-J, Cho Y-S (2014) Physiological components of kiwifruits with in vitro antioxidant and acetylcholinesterase inhibitory activities. Food Sci Biotechnol 23(3):943-949

35. Beck K, Conlon CA, Kruger R, Coad J, Stonehouse W (2010) Gold kiwifruit consumed with an iron-fortified breakfast cereal meal improves iron status in women with low iron stores: a 16-week randomised controlled trial. Br J Nutr 105(1):101-109. https://doi.org/10.1017/S0007114510003144

36. WHO Guidelines Approved by the Guidelines Review Committee (2012) In: Guideline: daily iron and folic acid supplementation in pregnant women. World Health Organization, Geneva
37. Food and Nutrition Board (Institute of Medicine) (2001) Dietary reference intakes for vitamin $\mathrm{A}$, vitamin $\mathrm{K}$, arsenic, boron, chromium, copper, iodine, iron, manganese, molybdenum, nickel, silicon, vanadium, and zinc. National Acadamies Press, Washington, DC. http://www.nap.edu/

38. Beck K, Conlon C, Kruger R, Coad J, Stonehouse W (2010) The effect of gold kiwifruit consumed with an iron fortified breakfast cereal meal on iron status in women with low iron stores: A 16 week randomised controlled intervention study. BMC Public Health 10:(36)

39. Public Health England, Food Standards Agency (2016) National diet and nutrition survey. Results from years 5 and 6 (combined) of the Rolling Programme (2012/13-2-13/14). Public Health England, London

40. Carr AC, Pullar JM, Moran S, Vissers MCM (2012) Bioavailability of vitamin $\mathrm{C}$ from kiwifruit in non-smoking males: determination of 'healthy' and 'optimal' intakes. J Nutr Sci 1 (e14). https://doi.org/10.1017/jns.2012.15

41. Levine M, Conry-Cantilena C, Wang Y, Welch RW, Washko PW, Dhariwal KR, Park JB, Lazarev A, Graumlich JF, King J, Cantilena LR (1996) Vitamin C pharmacokinetics in healthy volunteers: evidence for a recommended dietary allowance. Proc Natl Acad Sci USA 93(8):3704-3709

42. Piqueras JA, Kuhne W, Vera-Villarroel P, van Straten A, Cuijpers $P$ (2011) Happiness and health behaviours in Chilean college students: a cross-sectional survey. BMC Public Health 11:443. https://doi.org/10.1186/1471-2458-11-443

43. Blanchflower DG, Oswald AJ, Stewart-Brown S (2012) Is psychological well-being linked to the consumption of fruit and vegetables? Soc Indic Res 114(3):785-801

44. White BA, Horwath CC, Conner TS (2013) Many apples a day keep the blues away-daily experiences of negative and positive affect and food consumption in young adults. Br J Health Psychol 18(4):782-798. https://doi.org/10.1111/bjhp.12021

45. Block G, Norkus E, Hudes M, Mandel S, Helzlsouer K (2001) Which plasma antioxidants are most related to fruit and vegetable consumption? Am J Epidemiol 154(12):1113-1118

46. Cheraskin E, Ringsdorf WM Jr, Medford FH (1976) Daily vitamin $\mathrm{C}$ consumption and fatigability. J Am Geriatr Soc 24(3):136-137

47. Rebouche CJ (1991) Ascorbic acid and carnitine biosynthesis. Am J Clin Nutr 54(6 Suppl):1147s-1152s

48. Ferguson AR, Ferguson LR (2003) Are kiwifruit really good for you? Acta Hort 610:131-138

49. Fiorentino A, Mastellone C, D’Abrosca B, Pacifico S, Scognamiglio M, Cefarelli G, Caputo R, Monaco P (2009) $\delta$-Tocomonoenol: a new vitamin $\mathrm{E}$ from kiwi (Actinidia chinensis) fruits. Food Chem 115(1):187-192

50. Chang W-H, Liu J-F (2009) Effects of kiwifruit consumption on serum lipid profiles and antioxidative status in hyperlipidemic subjects. Int J Food Sci Nutr 1-8. https://doi.org/10.1080/09637 480802063517 (iFirst article)

51. Richardson DP (2015) Developing the right public health strategies for folic acid and reduction of risk of neural tube defects (NTDs) in the United Kingdom. Eur J Nutr Food Saf 5(4):242-249

52. Hsieh CL, Huang SM, Chen LI, Yu CM, Wong CH, Peng RY (2016) Novel Approach of using nutraceutic-directed caloric antioxidant density and ion-ratio for evaluating fruit's health quality. J Food Sci 81(8):H2059-2068. https://doi. org/10.1111/1750-3841.13390

53. Rust $P$, Ekmekcioglu C (2016) Impact of salt intake on the pathogenesis and treatment of hypertension. Adv Exp Med Biol. https ://doi.org/10.1007/5584_2016_147

54. Drewnowski A, Maillot M, Rehm C (2012) Reducing the sodium-potassium ratio in the US diet: a challenge for public 
health. Am J Clin Nutr 96(2):439-444. https://doi.org/10.3945/ ajcn.111.025353

55. Perez V, Chang ET (2014) Sodium-to-potassium ratio and blood pressure, hypertension, and related factors. Adv Nutr (Bethesda, Md) 5(6):712-741. https://doi.org/10.3945/an.114.006783

56. Bailey RL, Parker EA, Rhodes DG, Goldman JD, Clemens JC, Moshfegh AJ, Thuppal SV, Weaver CM (2016) Estimating sodium and potassium intakes and their ratio in the American diet: data from the 2011-2012 NHANES. J Nutr. https://doi. org/10.3945/jn.115.221184

57. Mishra S, Monro JA (2012) Kiwifruit remnants from digestion in vitro have functional attributes of potential importance to health. Food Chem 135(4):2188-2194. https://doi. org/10.1016/j.foodchem.2012.06.102

58. Sims IM, Monro JA (2013) Fiber: Composition, structures, and functional properties. In: Boland M, Moughan PJ (eds) Advances in food and nutrition research: nutritional benefits of kiwifruit, vol 68. Academic Press, pp 81-99

59. Cummings JH, Antoine J-M, Azpiroz F, Bourdet-Sicard R, Brandtzaeg P, Calder PC, Gibson GR, Guarner F, Isolauri E, Pannemans D, Shortt C, Tuijtelaars S, Watzl B (2004) PASSCLAIM-Gut health and immunity. Eur J Nutr 43(Supp 2):118-173

60. McRorie JW Jr, McKeown NM (2017) Understanding the physics of functional fibers in the gastrointestinal tract: an evidence-based approach to resolving enduring misconceptions about insoluble and soluble fiber. J Acad Nutr Diet 117(2):251-264. https://doi.org/10.1016/j.jand.2016.09.021

61. Ansell J, Parkar S, Paturi G, Rosendale D, Blatchford PA (2013) Modification of the colonic microbiota. In: Boland M, Moughan PJ (eds) Nutritional Benefits of kiwifruit. Advances in food and nutrition research, vol 68. Elsevier, pp 205-217

62. Pérez AG, Olías R, Espada J, Olías JM, Sanz C (1997) Rapid determination of sugars, nonvolatile acids, and ascorbic acid in strawberry and other fruits. J Agric Food Chem 45(9):35453549. https://doi.org/10.1021/jf9701704

63. Nishiyama II, Fukuda T, Shimohashi A, Oota T (2008) Sugar and organic acid composition in the fruit juice of different actinidia varieties. Food Sci Technol Res 14 (1):67-73

64. Mishra S, Edwards H, Hedderley D, Podd J, Monro J (2017) Kiwifruit non-sugar components reduce glycaemic response to co-ingested cereal in humans. Nutrients. https://doi. org/10.3390/nu9111195

65. Rush E, Drummond LN (2009) The glycaemic index of kiwifruit. N Z Kiwifruit J 192(May/June):29-33

66. Chen YY, Wu PC, Weng SF, Liu JF (2011) Glycemia and peak incremental indices of six popular fruits in Taiwan: healthy and Type 2 diabetes subjects compared. J Clin Biochem Nutr 49(3):195-199. https://doi.org/10.3164/jcbn.11-11

67. Latocha P, Krupa T, Wołosiak R, Worobiej E, Wilczak J (2010) Antioxidant activity and chemical difference in fruit of different Actinidia sp. Int J Food Sci Nutr 61(4):381-394. https:// doi.org/10.3109/09637480903517788

68. Fiorentino A, D'Abrosca B, Pacifico S, Mastellone C, Scognamiglio M, Monaco P (2009) Identification and assessment of antioxidant capacity of phytochemicals from kiwi fruits. J Agric Food Chem 57(10):4148-4155. https://doi. org/10.1021/jf900210z

69. Park Y-S, Jung S-T, Kang S-G, Drzewiecki J, Namiesnik J, Haruenkit R, Barasch D, Trakhtenberg S, Gorinstein S (2006) In vitro studies of polyphenols, antioxidants and other dietary indices in kiwifruit (Actinidia deliciosa). Int J Food Sci Nutr 57(1-2): 107-122

70. Du G, Li M, Ma F, Liang D (2009) Antioxidant capacity and the relationship with polyphenol and Vitamin C in Actinidia fruits. Food Chem 13(2):557-562
71. Wojdyło A, Nowicka P, Oszmiański J, Golis T (2017) Phytochemical compounds and biological effects of Actinidia fruits. J Funct Foods 30:194-202. https://doi.org/10.1016/j. jff.2017.01.018

72. Montefiori M, McGhie TK, Costa G, Ferguson AR (2005) Pigments in the fruit of red-fleshed kiwifruit (Actinidia chinensis and Actinidia deliciosa). J Agric Food Chem 53(24):9526-9530

73. Pérez-Burillo S, Oliveras MJ, Quesada J, Rufián-Henares JA, Pastoriza S (2018) Relationship between composition and bioactivity of persimmon and kiwifruit. Food Res Int 105:461-472. https://doi.org/10.1016/j.foodres.2017.11.022

74. Park YS, Namiesnik J, Vearasilp K, Leontowicz H, Leontowicz M, Barasch D, Nemirovski A, Trakhtenberg S, Gorinstein S (2014) Bioactive compounds and the antioxidant capacity in new kiwi fruit cultivars. Food Chem 165:354-361. https://doi. org/10.1016/j.foodchem.2014.05.114

75. Leontowicz H, Leontowicz M, Latocha P, Jesion I, Park YS, Katrich E, Barasch D, Nemirovski A, Gorinstein S (2016) Bioactivity and nutritional properties of hardy kiwi fruit Actinidia arguta in comparison with Actinidia deliciosa 'Hayward' and Actinidia eriantha 'Bidan'. Food Chem 196:281-291. https://doi. org/10.1016/j.foodchem.2015.08.127

76. Wang H, Cao G, Prior RL (1996) Total antioxidant capacity of fruits. J Agric Food Chem 44(3):701-705

77. Beekwilder J, Hall RD, de Vos CH (2005) Identification and dietary relevance of antioxidants from raspberry. Biofactors 23(4):197-205

78. Wilson DW, Nash P, Buttar HS, Griffiths K, Singh R, De Meester F, Horiuchi R, Takahashi T (2017) The role of food antioxidants, benefits of functional foods, and influence of feeding habits on the health of the older person: an overview. Antioxidants (Basel Switzerland). https://doi.org/10.3390/antiox6040081

79. Svendsen M, Tonstad S, Heggen E, Pedersen TR, Seljeflot I, Bohn SK, Bastani NE, Blomhoff R, Holme IM, Klemsdal TO (2015) The effect of kiwifruit consumption on blood pressure in subjects with moderately elevated blood pressure: a randomized, controlled study. Blood Press 24(1):48-54. https://doi. org/10.3109/08037051.2014.976979

80. Karlsen A, Svendsen M, Seljeflot I, Laake P, Duttaroy AK, Drevon CA, Arnesen H, Tonstad S, Blomhoff R (2012) Kiwifruit decreases blood pressure and whole-blood platelet aggregation in male smokers. J Hum Hypertens. https://doi.org/10.1038/ jhh.2011.116

81. Bohn S, Myhrstad M, Thoresen M, Holden M, Karlsen A, Tunheim S, Erlund I, Svendsen M, Seljeflot I, Moskaug J, Duttaroy A, Laake P, Arnesen H, Tonstad S, Collins A, Drevon C, Blomhoff R (2010) Blood cell gene expression associated with cellular stress defense is modulated by antioxidant-rich food in a randomised controlled clinical trial of male smokers. BMC Med 8(1):54

82. Brevik A, Gaivão I, Medin T, Jørgenesen A, Piasek A, Elilasson J, Karlsen A, Blomhoff R, Veggan T, Duttaroy AK, Collins AR (2011) Supplementation of a western diet with golden kiwifruits (Actinidia chinensis var.'Hort 16A':) effects on biomarkers of oxidation damage and antioxidant protection. Nutr J. https://doi. org/10.1186/1475-2891-10-54

83. Dizdarevic LL, Biswas D, Uddin MD, Jorgenesen A, Falch E, Bastani NE, Duttaroy AK (2014) Inhibitory effects of kiwifruit extract on human platelet aggregation and plasma angiotensinconverting enzyme activity. Platelets 25(8):567-575. https://doi. org/10.3109/09537104.2013.852658

84. Duttaroy AK, Jørgensen A (2004) Effects of kiwi fruit consumption on platelet aggregation and plasma lipids in healthy human volunteers. Platelets 15(5):287-292 
85. Prior RL, Gu L, Wu X, Jacob RA, Sotoudeh G, Kader AA, Cook RA (2007) Plasma antioxidant capacity changes following a meal as a measure of the ability of a food to alter in vivo antioxidant status. J Am Coll Nutr 26(2):170-181

86. He M, Zeng J, Zhai L, Liu Y, Wu H, Zhang R, Li Z, Xia E (2017) Effect of in vitro simulated gastrointestinal digestion on polyphenol and polysaccharide content and their biological activities among 22 fruit juices. Food Res Int (Ottawa Ont) 102:156-162. https://doi.org/10.1016/j.foodres.2017.10.001

87. Quan W, Tao Y, Lu M, Yuan B, Chen J, Zeng M, Qin F, Guo F, He Z Stability of the phenolic compounds and antioxidant capacity of five fruit (apple, orange, grape, pomelo and kiwi) juices during in vitro-simulated gastrointestinal digestion. Int J Food Sci Technol. https://doi.org/10.1111/ijfs.13682

88. Haminiuk CWI, Maciel GM, Plata-Oviedo MSV, Peralta RM (2012) Phenolic compounds in fruits-an overview. Int J Food Sci Technol 47(10):2023-2044. https://doi.org/10.111 1/j.1365-2621.2012.03067.x

89. Park YS, Im MH, Ham KS, Kang SG, Park YK, Namiesnik J, Leontowicz H, Leontowicz M, Katrich E, Gorinstein S (2013) Nutritional and pharmaceutical properties of bioactive compounds in organic and conventional growing kiwifruit. Plant Foods Hum Nutr 68(1):57-64. https://doi.org/10.1007/s1113 0-013-0339-z

90. Giangrieco I, Proietti S, Moscatello S, Tuppo L, Battistelli A, La Cara F, Tamburrini M, Famiani F, Ciardiello MA (2016) Influence of geographical location of orchards on green kiwifruit bioactive components. J Agric Food Chem 64(48):9172-9179. https ://doi.org/10.1021/acs.jafc.6b03930

91. Yoshihara D, Fujiwara N, Suzuki K (2010) Antioxidants: benefits and risks for long-term health. Maturitas 67(2):103-107. https:// doi.org/10.1016/j.maturitas.2010.05.001

92. Lewis DA, Luh BS (1988) Development and distribution of Actinidin in kiwifruit (Actinidia chinensis) and its partial characterization. J Food Biochem 12(2):109-116. https://doi. org/10.1111/j.1745-4514.1988.tb00363.x

93. Arcus AC (1959) Proteolytic enzyme of Actinidia chinensis. Biochim Biophys Acta 33(1):242-244

94. Grozdanovic MM, Ostojic S, Aleksic I, Andjelkovic U, Petersen A, Gavrovic-Jankulovic M (2014) Active actinidin retains function upon gastro-intestinal digestion and is more thermostable than the E-64-inhibited counterpart. J Sci Food Agric. https:// doi.org/10.1002/jsfa.6656

95. Bayer SB, Gearry RB, Drummond LN (2017) Putative mechanisms of kiwifruit on maintenance of normal gastrointestinal function. Crit Rev Food Sci Nutr. https://doi.org/10.1080/10408 398.2017.1327841

96. Sun Q, Zhang B, Yan QJ, Jiang ZQ (2016) Comparative analysis on the distribution of protease activities among fruits and vegetable resources. Food Chem 213:708-713. https://doi. org/10.1016/j.foodchem.2016.07.029

97. Cavic M, Grozdanovic MM, Bajic A, Jankovic R, Andjus PR, Gavrovic-Jankulovic M (2014) The effect of kiwifruit (Actinidia deliciosa) cysteine protease actinidin on the occludin tight junction network in T84 intestinal epithelial cells. Food Chem Toxicol Int J Publ Br Ind Biol Res Assoc 72c:61-68. https://doi. org/10.1016/j.fct.2014.07.012

98. Palacin A, Rodriguez J, Blanco C, Lopez-Torrejon G, SanchezMonge R, Varela J, JimÈnez MA, Cumplido J, Carrillo T, Crespo JF, Salcedo G (2008) Immunoglobulin E recognition patterns to purified Kiwifruit (Actinidinia deliciosa) allergens in patients sensitized to Kiwi with different clinical symptoms. Clin Exp Allergy 38(7):1220-1228

99. Lucas JSA, Grimshaw KEC, Collins K, Warner JO, Hourihane JOB (2004) Kiwi fruit is a significant allergen and is associated with differing patterns of reactivity in children and adults. Clin Exp Allergy 34(7):1115-1121

100. Gammon CS, Kruger R, Minihane AM, Conlon CA, von Hurst PR, Stonehouse W (2012) Kiwifruit consumption favourably affects plasma lipids in a randomised controlled trial in hypercholesterolaemic men. Br J Nutr FirstView:1-11. https://doi. org/10.1017/S0007114512004400 doi

101. Lucas JSA, Atkinson RG (2008) What is a food allergen? Clin Exp Allergy 38(7):1095-1099. https://doi.org/10.111 1/j.1365-2222.2008.02988.x

102. Fiocchi A, Restani P, Berbardo L, Martelli A, Ballabio C, D’Auria E, Riva E (2004) Tolerance of Heat-treated kiwi by children with kiwifruit allergy. Pediatr Allergy Immunol 15(5):454-458

103. Chen L, Lucas JS, Hourihane JO, Lindemann J, Taylor SL, Goodman RE (2006) Evaluation of IgE binding to proteins of hardy (Actinidia arguta), gold (Actinidia chinensis) and green (Actinidia deliciosa) kiwifruits and processed hardy kiwifruit concentrate, using sera of individuals with food allergies to green kiwifruit. Food Chem Toxicol 44(7):1100-1107

104. Tuppo L, Giangrieco I, Palazzo P, Bernardi ML, Scala E, Carratore V, Tamburrini M, Mari A, Ciardiello MA (2008) Kiwellin, a modular protein from green and gold kiwi fruits: evidence of in vivo and in vitro processing and IgE binding. J Agric Food Chem 56(10):3812-3817. https://doi.org/10.1021/jf703620m

105. Hamiaux C, Maddumage R, Middleditch MJ, Prakash R, Brummell DA, Baker EN, Atkinson RG (2014) Crystal structure of kiwellin, a major cell-wall protein from kiwifruit. J Struct Biol 187(3):276-281. https://doi.org/10.1016/j.jsb.2014.07.005

106. Ciacci C, Russo I, Bucci C, Iovino P, Pellegrini L, Giangrieco I, Tamburrini M, Ciardiello MA (2014) The kiwi fruit peptide kissper displays anti-inflammatory and anti-oxidant effects in invitro and ex-vivo human intestinal models. Clin Exp Immunol 175(3):476-484. https://doi.org/10.1111/cei.12229

107. Talley NJ, Holtmann G, Walker MM (2015) Therapeutic strategies for functional dyspepsia and irritable bowel syndrome based on pathophysiology. J Gastroenterol 50(6):601-613. https://doi. org/10.1007/s00535-015-1076-x

108. Foxx-Orenstein AE (2016) New and emerging therapies for the treatment of irritable bowel syndrome: an update for gastroenterologists. Ther Adv Gastroenterol 9(3):354-375. https://doi. org/10.1177/1756283x16633050

109. North CS, Hong BA, Alpers DH (2007) Relationship of functional gastrointestinal disorders and psychiatric disorders: implications for treatment. World J Gastroenterol 13(14):2020-2027

110. Bharucha AE, Pemberton JH, Locke GR, 3rd (2013) American gastroenterological association technical review on constipation. Gastroenterology 144 (1):218-238. https://doi.org/10.1053/j. gastro.2012.10.028

111. Lovell RM, Ford AC (2012) Global prevalence of and risk factors for irritable bowel syndrome: a meta-analysis. Clinical gastroenterology and hepatology: the official clinical practice. J Am Gastroenterol Assoc 10(7):712-721.e714. https://doi.org/10.1016/j. cgh.2012.02.029

112. Mearin F, Lacy BE, Chang L, Chey WD, Lembo AJ, Simren M, Spiller R (2016) Bowel disorders. Gastroenterology. https://doi. org/10.1053/j.gastro.2016.02.031

113. Ansell J, Butts CA, Paturi G, Eady SL, Wallace AJ, Hedderley D, Gearry RB (2015) Kiwifruit-derived supplements increase stool frequency in healthy adults: a randomized, double-blind, placebo-controlled study. Nutr Res (New York NY) 35(5):401408. https://doi.org/10.1016/j.nutres.2015.04.005

114. Rush EC, Patel M, Plank LD, Ferguson LR (2002) Kiwifruit promotes laxation in the elderly. Asia Pac J Clin Nutr 11(2):164-168

115. Chang C-C, Lin Y-T, Lu Y-T, Liu Y-S, Liu J-F (2010) Kiwifruit improves bowel function in patients with irritable bowel syndrome with constipation. Asia Pac J Clin Nutr 19(4):451-457 
116. Halmos EP, Power VA, Shepherd SJ, Gibson PR, Muir JG (2014) A diet low in FODMAPs reduces symptoms of irritable bowel syndrome. Gastroenterology 146(1):67-75.e65. https://doi. org/10.1053/j.gastro.2013.09.046

117. Bassotti G, Chistolini F, Marinozzi G, Morelli A (2003) Abnormal colonic propagated activity in patients with slow transit constipation and constipation-predominant irritable bowel syndrome. Digestion 68(4):178-183

118. Voderholzer WA, Schatke W, Muhldorfer BE, Klauser AG, Birkner B, Muller-Lissner SA (1997) Clinical response to dietary fiber treatment of chronic constipation. Am J Gastroenterol 92(1):95-98

119. Brownlee IA (2011) The physiological roles of dietary fibre. Food Hydrocolloids 25(2):238-250. https://doi.org/10.1016/j. foodhyd.2009.11.013

120. Chaplin MF (2003) Fibre and water binding. Proc Nutr Soc 62(1):223-227

121. Muller-Lissner SA, Kamm MA, Scarpignato C, Wald A (2005) Myths and misconceptions about chronic constipation. Am J Gastroenterol 100(1):232-242. https://doi.org/10.111 1/j.1572-0241.2005.40885.x

122. McIntyre A, Vincent RM, Perkins AC, Spiller RC (1997) Effect of bran, ispaghula, and inert plastic particles on gastric emptying and small bowel transit in humans: the role of physical factors. Gut 40(2):223-227

123. Müller-Lissner SA (1998) Effect of wheat bran on weight of stool and gastrointestinal transit time: a meta-analysis. BMJ 296(6622):615-617

124. EFSA Panel on Dietetic Products Nutrition and Allergies (NDA) (2010) Scientific opinion on dietary reference values for carbohydrates and dietary fibre. EFSA J 8(3):1462. https://doi. org/10.2903/j.efsa.2009.1221

125. Carnachan SM, Bootten TJ, Mishra S, Monro JA, Sims IM (2012) Effects of simulated digestion in vitro on cell wall polysaccharides from kiwifruit (Actinidia spp.). Food Chem 133(1):132139. https://doi.org/10.1016/j.foodchem.2011.12.084

126. Robertson JA, de Monredon FD, Dysseler P, Guillon F, Amado R, Thibault J-F (2000) Hydration properties of dietary fibre and resistant starch: a european collaborative study. LWT Food Sci Technol 33(2):72-79. https://doi.org/10.1006/fstl.1999.0595

127. Monro JA (2013) Fiber: composition, structures, and functional properties. In: Boland M, Moughan PJ (eds) Advances in food and nutrition research: nutritional benefits of kiwifruit, vol 68 . Academic Press, pp 257-272

128. Montoya CA, Rutherfurd SM, Olson TD, Purba AS, Drummond LN, Boland MJ, Moughan PJ (2014) Actinidin from kiwifruit (Actinidia deliciosa cv. Hayward) increases the digestion and rate of gastric emptying of meat proteins in the growing pig. $\mathrm{Br}$ J Nutr. https://doi.org/10.1017/s0007114513003401

129. Henare SJ, Rutherfurd SM (2013) Kiwifruit fiber digestion. In: Boland M, Moughan PJ (eds) Nutritional benefits of kiwifruit. Advances in Food and Nutrition Research, vol 68. Elsevier, pp 187-203

130. Chan AOO, Leung G, Tong T, Wong NYH (2007) Increasing dietary fiber intake in terms of kiwifruit improves constipation in Chinese patients. World J Gastroenterol 13(35):4771-4775

131. Monro JA, Paturi G, Mishra S (2017) Effects of kiwifruit and mixed dietary fibre on faecal properties and microbiota in rats: a dose-response analysis. Int J Food Sci Technol. https://doi. org/10.1111/ijfs. 13491

132. Montoya CA, Rutherfurd SM, Moughan PJ (2016) Kiwifruit fibre level influences the predicted production and absorption of SCFA in the hindgut of growing pigs using a combined in vivo-in vitro digestion methodology. Br J Nutr 115(8):1317-1324. https://doi. org/10.1017/s0007114515002883
133. Barbara G, Stanghellini V, Brandi G, Cremon C, Nardo GD, De Giorgio R, Corinaldesi R (2005) Interactions between commensal bacteria and gut sensorimotor function in health and disease. Am J Gastroenterol 100(11):2560-2568

134. Montoya CA, Rutherfurd SM, Moughan PJ (2017) Ileal digesta nondietary substrates from cannulated pigs are major contributors to in vitro human hindgut short-chain fatty acid production. J Nutr 147(2):264-271. https://doi.org/10.3945/jn.116.240564

135. Rosendale DI, Blatchford PA, Sims IM, Parkar SG, Carnachan SM, Hedderley D, Ansell J (2012) Characterizing kiwifruit carbohydrate utilisation in vitro and its consequences for human faecal microbiota. J Proteome Res. https://doi.org/10.1021/ pr300646m

136. Blatchford P, Bentley-Hewitt KL, Stoklosinski H, McGhie T, Gearry R, Gibson G, Ansell J (2015) In vitro characterisation of the fermentation profile and prebiotic capacity of goldfleshed kiwifruit. Benef Microbes 6(6):829-839. https://doi. org/10.3920/bm2015.0006

137. Reimer RA, Pelletier X, Carabin IG, Lyon MR, Gahler RJ, Wood S (2012) Faecal short chain fatty acids in healthy subjects participating in a randomised controlled trial examining a soluble highly viscous polysaccharide versus control. J Human Nutr Diet 25(4):373-377. https://doi.org/10.1111/j.1365277X.2012.01230.X

138. Donaldson B, Rush E, Young O, Winger R (2014) Variation in gastric $\mathrm{pH}$ may determine kiwifruit's Effect on functional GI disorder: an in vitro study. Nutrients 6(4):1488-1500. https:// doi.org/10.3390/nu6041488

139. Martin H, Cordiner SB, McGhie TK (2017) Kiwifruit actinidin digests salivary amylase but not gastric lipase. Food Funct. https://doi.org/10.1039/c7fo00914c

140. Hiele M (2010) Effect of consumption of kiwifruit on constipation in adults. In: Confidential report to Zespri International Ltd. Gastroenterology Department, Catholic University of Leuven, Belgium

141. Cunillera O, Almeda J, Mascort JJ, Basora J, Marzo-Castillejo M (2015) Improvement of functional constipation with kiwifruit intake in a Mediterranean patient population. An open, non-randomized pilot study. Revista española de nutrición humana y dietética 19(2):10

142. Ohsawa H, Okawa M, Ebihara T (2010) Effect of kiwifruit on defecation and skin condition in subjects prone to constipation. In: Confidential Report to Zespri International Ltd. RD Support and Chiyoda Paramedical Care Clinic, Tokyo

143. Wallace A, Eady S, Drummond L, Hedderley D, Ansell J, Gearry R (2017) A pilot randomized cross-over trial to examine the effect of kiwifruit on satiety and measures of gastric comfort in healthy adult males. Nutrients. https://doi. org/10.3390/nu9070639

144. Gearry RB, Barbara G, Fukudo S, Ansell J, Eady S, Wallace A, Butts CA, Dinnan H, Kuhn-Sherlock B, Drummond LN (2017) The effect of Zespri ${ }^{\mathrm{TM}}$ green kiwifruit on constipation and abdominal discomfort: a controlled randomized cross-over intervention study. Gastroenterology 152(5):S917

145. Shepherd SJ, Lomer MC, Gibson PR (2013) Short-chain carbohydrates and functional gastrointestinal disorders. Am J Gastroenterol 108(5):707-717. https://doi.org/10.1038/ajg.2013.96

146. Eswaran S (2017) Low FODMAP in 2017: Lessons learned from clinical trials and mechanistic studies. Neurogastroenterol Motil Off J Eur Gastrointest Motil Soc. https://doi.org/10.1111/ nmo. 13055

147. Hill P, Muir JG, Gibson PR (2017) Controversies and recent developments of the low-FODMAP diet. Gastroenterol Hepatol (N Y) 13(1):36-45

148. Marsh A, Eslick EM, Eslick GD (2016) Does a diet low in FODMAPs reduce symptoms associated with functional 
gastrointestinal disorders? A comprehensive systematic review and meta-analysis. Eur J Nutr 55(3):897-906. https://doi. org/10.1007/s00394-015-0922-1

149. Wilder-Smith CH, Olesen SS, Materna A, Drewes AM (2017) Predictors of response to a low-FODMAP diet in patients with functional gastrointestinal disorders and lactose or fructose intolerance. Aliment Pharmacol Ther 45(8):1094-1106. https ://doi.org/10.1111/apt.13978

150. Chen A, Offereins MSL, Mulder CJ, Frampton CM, Gearry RB (2017) A pilot study if the effect of green kiwifruit on intestinal fermentation in humans as measured by hydrogen and methane breath testing (in submission)

151. DeFronzo RA, Abdul-Ghani M (2011) Assessment and treatment of cardiovascular risk in prediabetes: impaired glucose tolerance and impaired fasting glucose. Am J Cardiol 108(3 Suppl):3b-24b. https://doi.org/10.1016/j.amjcard.2011.03.013

152. Dzau VJ, Antman EM, Black HR, Hayes DL, Manson JE, Plutzky J, Popma JJ, Stevenson W (2006) The cardiovascular disease continuum validated: clinical evidence of improved patient outcomes: part I: Pathophysiology and clinical trial evidence (risk factors through stable coronary artery disease). Circulation 114(25):2850-2870. https://doi.org/10.1161/circulatio naha.106.655688

153. Gorelick PB, Scuteri A, Black SE, Decarli C, Greenberg SM, Iadecola C, Launer LJ, Laurent S, Lopez OL, Nyenhuis D, Petersen RC, Schneider JA, Tzourio C, Arnett DK, Bennett DA, Chui HC, Higashida RT, Lindquist R, Nilsson PM, Roman GC, Sellke FW, Seshadri S (2011) Vascular contributions to cognitive impairment and dementia: a statement for healthcare professionals from the American Heart Association/American Stroke Association. Stroke J Cerebral Circ 42(9):2672-2713. https://doi. org/10.1161/STR.0b013e3182299496

154. Mishra S, Willis J, Ansell J, Monro JA (2016) Equicarbohydrate partial exchange of kiwifruit for wheaten cereal reduces postprandial glycaemia without decreasing satiety. J Nutr Sci 5:e37. https://doi.org/10.1017/jns.2016.30

155. Coles LT, Moughan PJ, Awati A, Darragh AJ, Zou ML (2010) Predicted apparent digestion of energy-yielding nutrients differs between the upper and lower digestive tracts in rats and humans. J Nutr 140(3):469-476. https://doi.org/10.3945/jn.109.116293
156. Henare SJ, Rutherfurd SM, Drummond LN, Borges V, Boland MJ, Moughan PJ (2012) Digestible nutrients and available (ATP) energy contents of two varieties of kiwifruit (Actinidia deliciosa and Actinidia chinensis). Food Chem 130(1):67-72

157. Stonehouse W, Gammon CS, Beck KL, Conlon CA, Von Hurst PR, Kruger R (2013) Kiwifruit: our daily prescription for health. Can J Physiol Pharmacol 91(6):42-47. https://doi.org/10.1139/ cjpp-2012-0303

158. Chang W-H, Liu J-F (2009) Effects of kiwifruit consumption on serum lipid profiles and antioxidative status in hyperlipidemic subjects. Int J Food Sci Nutr (on line) (1):1-8

159. Gammon CS, Kruger R, Brown SJ, Conlon CA, von Hurst PR, Stonehouse W (2014) Daily kiwifruit consumption did not improve blood pressure and markers of cardiovascular function in men with hypercholesterolemia. Nutr Res 34(3):235-240. https ://doi.org/10.1016/j.nutres.2014.01.005

160. Jung K-A, Song T-C, Han D, Kim I-H, Kim Y-E, Lee C-H (2005) Cardiovascular protective properties of kiwifruit extracts in vitro. Biol Pharmaceut Bull

161. Aune D, Giovannucci E, Boffetta P, Fadnes LT, Keum N, Norat T, Greenwood DC, Riboli E, Vatten LJ, Tonstad S (2017) Fruit and vegetable intake and the risk of cardiovascular disease, total cancer and all-cause mortality-a systematic review and doseresponse meta-analysis of prospective studies. Int $\mathrm{J}$ Epidemiol. https://doi.org/10.1093/ije/dyw319

162. Zino S, Skeaff M, Williams S, Mann J (1997) Randomised controlled trial of effect of fruit and vegetable consumption on plasma concentrations of lipids and antioxidants. BMJ 314(7097): 1787

163. Cremon C, Pagano I, Marcellini MM, Barbaro MR, Gearry R, Fukudo S, Drummond L, Ansell J, Mauloni P, Capelli E, Stanghellini V, Barbara G (2017) The effect of Zespri green kiwifruit on digestive and gut health functions. Neurogastroenterol Motil 29:29-30

164. Foley A, Burgell R, Barrett JS, Gibson PR (2014) Management strategies for abdominal bloating and distension. Gastroenterol Hepatol (N Y) 10(9):561-571 